NBER WORKING PAPER SERIES

HEALTH VS. WEALTH? PUBLIC HEALTH POLICIES AND THE ECONOMY DURING COVID-19

Zhixian Lin

Christopher M. Meissner

Working Paper 27099

http://www.nber.org/papers/w27099

\author{
NATIONAL BUREAU OF ECONOMIC RESEARCH \\ 1050 Massachusetts Avenue \\ Cambridge, MA 02138 \\ May 2020, Revised November 2020
}

We thank Haoze "Anson" Li and Jingxuan Ma for research assistance. Research funding from Michael Deering is gratefully acknowledged. We thank Jonathan Dingel for clarifying some data issues. Matthias Blum, Barry Eichengreen, Gregori Galofré-Vilà, Dan Liu, Peter Sandholt Jensen, Peter Lindert, Alan M. Taylor and seminar participants at UC Davis provided helpful early feedback. The views expressed herein are those of the authors and do not necessarily reflect the views of the National Bureau of Economic Research.

NBER working papers are circulated for discussion and comment purposes. They have not been peer-reviewed or been subject to the review by the NBER Board of Directors that accompanies official NBER publications.

(C) 2020 by Zhixian Lin and Christopher M. Meissner. All rights reserved. Short sections of text, not to exceed two paragraphs, may be quoted without explicit permission provided that full credit, including $\left({ }^{\circ}\right.$ notice, is given to the source. 
Health vs. Wealth? Public Health Policies and the Economy During Covid-19

Zhixian Lin and Christopher M. Meissner

NBER Working Paper No. 27099

May 2020, Revised November 2020

JEL No. E24,E3,E71,Z18

\begin{abstract}
$\underline{\text { ABSTRACT }}$
We study the impact of non-pharmaceutical policy interventions (NPIs) like "stay-at-home" orders on the spread of infectious disease. Local policies have little impact on the economy nor on local public health. Stay-at-home is only weakly associated with slower growth of Covid-19 cases. Reductions in observed "mobility" are not associated with slower growth of Covid-19 cases. Stay-at-home is associated with lower workplace and more residential activity, but common shocks matter much more. Moreover, job losses have been no higher in US states that implemented stay-at-home during the Covid-19 pandemic than in states that did not have stay-athome. All of these results demonstrate that the Covid-19 pandemic is a common economic and public health shock. They also show that policy spillovers and behavioral responses are important. The tradeoff between the economy and public health in a pandemic depends strongly on what is happening elsewhere. This underscores the importance of coordinated economic and public health responses.
\end{abstract}

Zhixian Lin

California Center for Population Research at UCLA

4284 Public Affairs Bldg., MC 723603

337 Charles E. Young Dr. East

90095

Los Angeles, CA 90095

zxlin@ucla.edu

Christopher M. Meissner

Department of Economics

University of California, Davis

One Shields Avenue

Davis, CA 95616

and NBER

cmmeissner@ucdavis.edu 


\title{
Health vs. Wealth? Public Health Policies and the Economy During Covid-19
}

\section{November 11, 2020}

\author{
Peter Zhixian Lin \\ University of California, Davis
}

Christopher M. Meissner

University of California, Davis \& NBER*

\begin{abstract}
We study the impact of non-pharmaceutical policy interventions (NPIs) like "stay-at-home" orders on the spread of infectious disease. Local policies have little impact on the economy nor on local public health. Stay-at-home is only weakly associated with slower growth of Covid-19 cases. Reductions in observed "mobility" are not associated with slower growth of Covid-19 cases. Stay-at-home is associated with lower workplace and more residential activity, but common shocks matter much more. Moreover, job losses have been no higher in US states that implemented stay-at-home during the Covid-19 pandemic than in states that did not have stay-at-home. All of these results demonstrate that the Covid-19 pandemic is a common economic and public health shock. They also show that policy spillovers and behavioral responses are important. The tradeoff between the economy and public health in a pandemic depends strongly on what is happening elsewhere. This underscores the importance of coordinated economic and public health responses.
\end{abstract}

\section{Introduction}

We study the local health and economic impacts of non-pharmaceutical public health interventions (NPIs) like "stay-at-home" on the spread of Covid-19. Since December 2019, Covid-19 has spread to nearly all countries in the world. Every state and territory in the USA has reported at least one case. Theoretical and empirical literature in epidemiology and public health has argued, based on experience from the 1918-20 influenza pandemic, that NPIs can be important in decreasing local peak mortality and cumulative mortality (Hatchett

* Corresponding author: Christopher M. Meissner University of California, Davis One shields Avenue, Davis, CA, 95616. cmm@ucdavis.edu We thank Haoze "Anson" Li and Jingxuan Ma for research assistance. Research funding from Michael Deering is gratefully acknowledged. We thank Jonathan Dingel for clarifying some data issues. Matthias Blum, Barry Eichengreen, Gregori Galofré-Vilà, Dan Liu, Peter Sandholt Jensen, Peter Lindert, Alan M. Taylor and seminar participants at UC Davis provided helpful early feedback. 
et. al, 2007; Markel et. al, 2007; Bootsma and Ferguson, 2007 and Barro, 2020). ${ }^{1}$ Countries, states, counties, and cities recently imposed a number of NPIs to enhance social distancing with the aim of mitigating the spread of Covid-19. Have these had benefits for public health but at the cost of the economy? The recent Covid-19 pandemic and associated staggered implementation of local NPIs allows us to gauge whether such policies have been effective for public health today and if there are economic costs to these policies.

We have three main results using data from US states and counties. Our county analysis uses a border discontinuity design in a sample of contiguous counties spanning state borders. This allows us control for unobservable heterogeneity at the local level while still achieving variation in policy choices. First, our analysis shows NPIs are only weakly associated with slower growth rates of confirmed cases of Covid-19 at the state level. ${ }^{2}$ These results are likely due to reverse causality, selection or spillovers. When we compare US counties with "stay-at-home" to counties across a state-border where there is no "stay-athome" order, there is no differential effect of these NPIs on the growth rate of confirmed cases. This could be evidence that policy changes have spillovers on behavior in other states.

Our second main result is about spillovers. We show that NPIs from other states may matter for local outcomes. Policies in other states potentially alter the information set even in places without NPIs resulting in seemingly coordinated behavior. Behavioral changes, even in the absence of policy could also be important. Third, there is little evidence that local stay-at-home orders are associated with declines in local economic activity that are substantively larger than in places without stay-at-home. Stay-at-home orders do limit "mobility" and activity around the workplace while boosting residential activity. Still, common shocks to the economy have much larger explanatory power in explaining economic outcomes.

Gauging the economic consequences of public health policies of global pandemics is challenging. Global pandemics are rare events (Barro et. al. 2020; Jordà et. al, 2020 and Correia et. al 2020), and economic theory has lagged somewhat. New insights combining economic and epidemiological modeling are emerging with new theoretical predictions. The key tradeoff is between public health and the economy (Gourinchas, 2020 Acemoglu et. al.

\footnotetext{
${ }^{1}$ Hatchett et. al. (2007) find local NPIs reduce "peak mortality" but find mostly statistically insignificant impacts on cumulative mortality in their sample of 17 cities in 1918-19. Barro (2020) finds the same in a broader sample of US cities for 1918-20. Dave et. al (2020) studies "shelter-in-place" in the US states during the Covid19 pandemic finding. They study the impact on the level of cases and deaths from Covid-19, and find, as we do in our state sample, that NPIs are associated with lower cases but are not statistically associated with deaths. They study how the impact of NPIs depends on various observable characteristics of states. They do not study spillovers nor the economic impact of NPIs as we do, nor do they have a county-level analysis. Courtemanche et. al. (2020) use the near-universe of US counties between 1 March and 27 April and find a negative impact of "shelter-in-place" on the growth rate of Covid-19 cases. They do not use a matched county pair sample as we do nor do they study the economic implications of NPIs as we do. Kahn et. al (2020) argue for a common shock and study UI claims, but do not estimate an explicit model as we do.

${ }^{2}$ We find no relationship between NPIs and the growth rate of cumulative mortality. We largely focus on the growth of confirmed cases economic outcomes.
} 
2020). ${ }^{3}$ In theory, aggressive NPIs benefit public health and help manage the health care resources in a pandemic, especially with limited medical capacity. In many theoretical models, NPIs may however damage the economy and create high levels of unemployment. But, even without policy, people pay attention to news and events elsewhere reacting with spontaneous social distancing (Eichenbaum et. al. 2020; Baldwin, 2020; Krueger et. al, 2020). There may also be important economic spillovers to NPIs (Beck and Wagner, 2020). Economic interdependence alters the tradeoff between disease and the economy by shifting the policy frontier representing the tradeoff (see Figure 1 in Acemoglu et. al., 2020).

A pandemic can impact an economy in many ways even without public health policy: reductions in people's willingness to work, dislocations in consumption patterns and lower consumption, added stress on the financial system, and greater uncertainty leading to lower investment. These are respectively referred to as (labor) supply shocks, demand shocks, financial shocks and uncertainty shocks. Connected economies and epidemiological communities also move in synch. Even a healthy economy, or an economy that has not mandated a shutdown, may feel the impact of external events. With the exception of the 1918-20 influenza, recent pandemics have neither had as large of a global impact, nor has there been as much real time data available to empirically assess the economic and public health impact of NPIs. We study outcomes during the Covid-19 pandemic and find little impact of NPIs on growth rates of cases, growth rates of deaths, and the economy. The policy tradeoff between health and the economy seems limited especially at the local level.

The reason we find no evidence consistent with a health/economy tradeoff is that epidemiological and economic shocks have been common to the US and indeed to the world. It is difficult to save a local economy when key trade partners' economies are suffering. ${ }^{4}$ Behavioral responses to the disease environment, independent of public health policy, also imply that outcomes are not entirely related to local policy choices - especially in the early stages of an outbreak.

We also address the issue of spillovers in NPI policy and public health: do local policies have effects on other jurisdictions and territories? We find they might, at least within the United States. Evidence based on mobility and activity from Google "mobility" reports, suggests behavior is highly correlated in neighboring states after policies that limit movement like stay-at-home are implemented. In light of this, delaying implementation of NPIs may have little extra economic benefit when significant trade partners have already implemented such policies and when information and disease travel rapidly. This evidence can account for the lack of a tradeoff between health and the economy.

\footnotetext{
${ }^{3}$ Adda (2016) studies the connection between NPIs and viral infections in a connected economy.

${ }^{4}$ Andersen et. al. find evidence that economic activity in Sweden and Denmark were highly correlated despite Sweden having imposed more limited NPIs than Denmark. Correia et. al (2020) find no economic negative impact of NPIs during the 1918-19 influenza in the US.
} 


\section{Methods}

\subsection{Data collection}

For public health data in US states and counties, we rely on confirmed cases and deaths of Covid-19 reported by the New York Times on a daily basis. These data are based on reports from state and local health agencies. We have data for 50 US States + the District of Columbia as well as over 2000 US counties. We use data for the US between 1 March 2020 and 25 April 2020 with exact samples depending on data availability. 25 is one of the last days before localities began to loosen their NPI policies.

Data on "stay-at-home" orders at the US state-level is from the official orders or announcements made by public health authorities at each state and is made available from the New York Times (see the data appendix for a description of stay-at-home and other NPIs). We also hand collected county-level data for various NPIs and county-level stay-athome orders for over 150 counties which are matched to counties along the state borders. To the best of our knowledge this is the first such systematic compilation of such countylevel data.

Eight states had no state-wide stay-at-home order (Arkansas, Iowa, North and South Dakota, Nebraska and Oklahoma, Utah, and Wyoming) according to the New York Times dataset we use. Several counties and localities in Utah and Wyoming issued stay-at-home orders despite no (or very late) state-wide coverage of stay-at-home. In Oklahoma about nine localities/counties including Tulsa and Oklahoma City issued stay-at-home orders. In other states such as Iowa, Nebraska and Arkansas, counties took action by closing schools, limiting public gatherings and closing dine-in restaurants or by issuing their own stay-athome orders. In general, no counties opted out of state-level restrictions until April 27th after our data ends.

Real-time data that helps understand the macro economy is relatively scarce and has only become available in recent decades. Recent research uses real time data from private financial (fin-tech) companies to track consumer spending as well as movement based on privately collected GPS signals from mobile phones. Such data is subject to measurement error, reports for limited and small samples, and cannot be considered as fully indicative of the macroeconomic situation (Baker et. al. 2020). Nevertheless, we rely on "mobility" data from Google as proxies for economic activity, and to gauge the impact of stay-at-home on behavior. These are daily data on number of visits and length of stay in particular types of locations (retail, grocery, parks, transportation hubs, workplaces, and residential areas). They are measured as the percentage deviation from a baseline established in January and early February 2020.

We also use initial claims for unemployment insurance published by the US Department of Labor (i.e., initial jobless claims) at the state level on a weekly basis. Each state's data are as of the end of the week (i.e., Saturday). We use data which are not 
seasonally adjusted and which are subject to revision. Initial jobless claims represent a consistent and reliable indicator of the US labor market at the local level, are of reasonable quality, and are often used as a leading indicator for macroeconomic forecasts. These data exclude the self-employed. We also supplement the economic data with information on the employment shares in selected industries we believe may be hardest hit in the recent months such as oil and gas extraction, retail, food processing/restaurants, wholesale and arts, recreation and leisure. We also use information on the share of jobs in a state that can be carried out at home to see if this mitigated the impact of stay-at-home (Dingel and Neiman, 2020).

\subsection{Data Analysis}

Our main dependent variables are the daily changes of the (natural) logarithm of cumulative confirmed cases or deaths of Covid-19. We acknowledge considerable debate about measurement error due to variable testing rates across localities. We allow for local county-pair specific shocks in order to avoid this potentially confounding effect. Potential for measurement error also exists for the mortality data. There have been cases of deaths at home from those not admitted to nor tested in hospitals. Using excess mortality is theoretically an option but systematic data is not readily available nor directly comparable.

We also use the logarithm of initial jobless claims at the state-level as a dependent variable. Data are not seasonally adjusted since such adjustments apply to all cross-sectional units (i.e., states) and are captured in period/day intercepts. Initial jobless claims are subject to revision. Our data end with information on the week ending 4 April. The latest revisions apply to weeks before and including the week ending 28 March, 2020.

In addition to state-level data, we use county level data in order to help define better control groups as in Dube et. al. (2010). Our US county sample matches contiguous counties from two different states that share a state border. As discussed in Dube et. al. (2010), using all neighbors of a given county as a control group is not feasible. At the US county-level we have total cases and deaths of Covid-19, stay-at-home orders (if different from the state), county-level NPIs, as well as the Google mobility data. We use cases of Covid-19 and the Google mobility data as dependent variables in an attempt to measure the impact of statelevel stay-at-home policies on health and the economy. We also investigate whether Covid19 cases and mobility are related directly.

State and county-level NPIs vary in their particular prescriptions. Many counties and states instituted NPIs like school closures, limited public gatherings and closed dine-in restaurants and casinos, etc. Stay-at-home orders at the state or county level typically mandate that people refrain from meeting in groups, limit physical social interaction to within households, and that people frequent only essential businesses. In person work is allowed only for "essential" businesses. 
Throughout our paper, we assume that the decision to adopt and the timing of NPIs and stay-at-home are exogenous and uncorrelated with unobservables especially expectations about the future path of mortality and the expected path of economic and social variables of interest. Still, we allow for leads of stay-at-home policies and show results from event studies to deal with the issues of reverse causality and pre-event trends.

We allow for policy spillovers by measuring the level of policies in all other states. In our international sample, we look at policies of other countries that share a border. Each policy in another state (or country) is divided by the centroid-to-centroid distance. For robustness we also population weighted each other state's distance weighted policy. States with closer proximity to the observation have a bigger potential spillover since we assume economic and social interactions are roughly linear in the log of physical distance with an elasticity of -1 . The measure for state $i$ of all other states' NPI policies is $S_{i,-i}=$

$\sum_{j \neq i} \frac{\left.1 \text { (Stay-at- }- \text { Home }_{j}=1\right)}{\text { distance }_{i j}}$. We also introduce the sum of policies in the states which share a border with state $i, S_{i,-i}^{\prime}=\sum_{n} 1$ (Stay-at-Home ${ }_{\mathrm{n}}=1$ ) where $n$ indexes states in the set $N$ of i's neighboring states. Similarly, we can control for the confirmed cases of other states with distance weighting and in neighboring states.

In all models we include controls for calendar weeks or calendar day fixed effects, state-level fixed effects and event-time trends (linear and quadratic, but cubic terms were tested). The event is defined either as the number of days elapsed between the current date and the date a state reached the first death or first confirmed case of Covid-19. We also cluster standard errors of estimated coefficients at the state level or employ two-way clustering as discussed below.

\section{Results: Policy, Public Health, and the Economy}

As of mid-April 2020, there were over one million confirmed cases in the United States. The US average growth rate of cases for the 56 days between 1 March (76 cases) and 25 April $(938,154$ cases) was $18.3 \%$. In New York state the number of cases grew from one on 2 March 2020 to 282,143 on 25 April (average growth rate $=25.63 \%$ ). Other populous states had slightly lower growth rates: Texas (20.14\%), California (14.8\%), and Florida (19.1\%). Deaths from Covid-19 began to grow quickly after the first week in March. New York's cumulative crude death rate from Covid-19 per 100,000 population grew to 113, the highest in the nation by 25 April. The next five states ranked on this metric (as of 25 April) were New Jersey (66), Massachusetts (39), Connecticut (52.3), and Louisiana (36.7). The states with the lowest rates were rural or more isolated from the continental United States: Utah (1.27), Alaska (1.23), Wyoming (1.20), South Dakota (1.13) and Hawaii (0.91). We now explore the determinants and economic environment surrounding these numbers. 


\subsection{Policies and Public Health}

Table 1 shows regression results relating the daily growth rate of Covid-19 cases and stay-at-home orders at the state-level using daily data. Regressions take the form

$$
\Delta \ln \left(\operatorname{cases}_{i t}\right)=\mu_{i}+\delta_{t}+\gamma\left(N P I_{i t}\right)+\text { time }_{i t}+\text { time }_{i t}^{2}+\varepsilon_{i t}
$$

where states are indexed by $i, N P I_{i t}$ is an indicator variable for whether the state had adopted a stay-at-home order on day $t, \delta_{t}$ is a set of calendar day fixed effects, time and its square measure event time as the number of days since the first death from Covid-19, and $\varepsilon_{i t}$ is an error term. Data are for 1 March through 25 April.

Column 1 of Table 1 shows that a state's own policy was associated with a reduction of the growth rate of $2.9 \log$ points ( $p$-value $=0.026,95 \%$ C.I. -0.003 to -0.053 ). Figure 1 shows the dynamics using an event study approach. We compare the change in the daily difference of log total confirmed cases in states with stay-at-home to those without this policy in each five day period before and after the policy change (nine coefficients). The omitted reference group is the six days up to and including the policy change. The point estimates are statistically significant only after a lag of about 26 days suggesting that policies reduced the growth rate of Covid-19 cases at the state level. ${ }^{5}$ There is no evidence of a pretrend in the growth rate of cases.

We continue our analysis by investigating policy spillovers between states from NPIs. A large majority of public schools across the nation were closed from around 16 March for instance. Other NPIs and stay-at-home were rolled out more progressively.

We test for spillovers in a linear regression in Table 1. In these regressions, we allow for stay-at-home policies in all other states to matter for state $i$. Policies in other states are population and distance weighted. We also allow for differential effects of policies of neighboring states' policy by policies in other states with a border state indicator dummy variable. We also allow for the level of confirmed cases in other states to affect growth of cumulative cases. We interact all other-state policies with an indicator for the calendar week to investigate how the timing of other state policies interacts with the cumulative policies up to that given week.

Own-state policies are always associated with lower growth rates of confirmed cases after controlling for other state policies. The point estimate after controlling for spillovers in column 4 is -0.021 (p-value $=0.071,95 \%$ C.I. -0.045 to 0.001 ). This is one-fourth of the magnitude of the own-state policy in column 1 of Table 1 when we do not control for other state policies.

Spillovers matter -- especially after groups 2 and 3 had adopted. Policies in other states dating from the week ending March 28th are negatively associated with growth of

\footnotetext{
${ }^{5}$ Courtemanche et. al. (2020) control for growth of testing capacity at the state level. We do not. They find no substantive impact on their point estimates of various NPIs in the regression model for state-level daily changes in total cases - a model almost identical to ours in terms of specification.
} 
cases even in states that had yet to impose a stay-at-home policy. The association between local growth rates of confirmed cases and the second group of states' policies is the largest. Column 4 shows the point estimate is -3.324 ( $p$-value $=0.00895 \%$ C.I. -.0 .92 to -5.72 ). An extra policy (in the week ending 28 March) at the median distance between states is associated with a decline of about one-fifth of a log point or $-0.002(-0.002=(1 / 1688) \mathrm{x}-$ 3.324). A new policy by a neighboring state, with the median in-sample centroid-to-centroid distance is associated with a decline of almost one log point or $-0.008\left(-0.008=(1 / 441)^{*}\right.$ 3.324). This is about one-third as large as the own-state point estimate. There is no statistically significant differential in the marginal impact of bordering states versus more distant states after accounting for distance between state centroids.

The association for stay-at-home policies in weeks 3 and 4 declines in absolute magnitude and statistical significance in columns 2-4. By the third week, the marginal effects of policies in other states are not statistically significant. This is suggestive of the idea that the wave of stay-at home policies at the state level implemented between March $19^{\text {th }}$ (California) and March 28th had a bigger impact than later waves. We also cannot reject the hypothesis that the level of deaths in other cities (weighted by distances between cities) has no relationship with own-city growth rates of cases ceteris paribus.

We now move to analysis of a matched border county sample. Regressions take the form

$$
\Delta \ln \left(\operatorname{cases}_{c t}\right)=\mu_{p}+\delta_{t}+\gamma\left(N P I_{s t}\right)+\text { time }_{c t}+\operatorname{time}_{c t}^{2}+\varepsilon_{c t}
$$

where counties are indexed by $c, N P I_{c t}$ is the county-level stay-at-home policy, $\mu_{p}$ is a set of county-pair fixed effects, and other variables are defined as in the state sample. Data are for 1 March through 25 April. Counties may appear in more than pair. We cluster standard errors at the state level and in the "border segment" which includes all of the border pairs for two states that share a border (e.g., all counties on the California/Nevada border would be in a border segment). We weight all regressions with county-population.

Along the state borders at the county level, stay-at-home policies are not associated with any differential impact on the growth of confirmed cases. Counties on the side of the border that had no stay-at-home have growth trajectories of cases similar to those counties with stay-at-home policies. Figure 2 shows results from an event study regression model with 6,068 county-day observations and 113 county pairs. It contrasts starkly with the statelevel results in Figure 1 which showed a pronounced decline in the growth rate of cases after implementation of stay-at-home. ${ }^{6}$

\footnotetext{
${ }^{6}$ We also ran an event study for the change in the logarithm of deaths from Covid-19. In the county matched border pair sample, there is no significant difference in these changes between stay-at-home counties and counties without stay-at-home. The change in log deaths is significantly lower in counties prior to adoption than in other non-adopting counties- suggesting a process of selection. If we use the earlier date for softer NPIs such as school closures and limited public gatherings, there is no significant impact of NPIs on the change in log deaths either. Also, in the state-level data, we see no statistically significant impact of stay-at-home on the change in the logarithm of deaths relative to states without stay-at-home.
} 
The results in Figure 2 are consistent with policy spillovers. People in counties without rigorous stay-at-home policy may have taken a behavioral cue from nearby counties/states with such policies. There is also the possibility that heterogeneity explains the differences between results in Figure 1 (state-level) and Figure 2 (county-level). Perhaps non-border/"interior" counties in states that adopted stay-at-home took other actions to limit spread, were more likely to socially distance themselves due to individual behavior or regulations, or were simply more apt to comply with stay-at-home than in states that did not have such a policy. Along the border, where the control group is more circumscribed, these differences dissipate. This implies local policy itself was unlikely to be the sole determinant of growth in cases in these places. Behavioral responses in counties without stay-at-home policy may still be affected by policy, but those policies may be in neighboring counties.

In Table A1 we regress the change in the logarithm of cases at the county level on Google mobility measures in our matched border sample. None of the mobility measures have a significant impact on the growth rate of cases. There seems to be no significant relationship between the growth of cases or deaths and the state of the local economy assuming that the mobility data are correlated with economic activity.

We show below that local stay-at-home policies seem to have been associated with some changes in the mobility indexes. However, the growth rate of cases is neither associated with stay-at-home nor measured mobility. The dominant factors explaining the growth in cases seem to be the calendar days and the time trends. It may be possible that the google mobility measures are poor measures of actual levels of social distancing or that other channels such as within family or within residence (e.g., nursing homes) transmission are dominant too.

\subsection{Policies and the Economy: Local Evidence}

We first analyze the impact of stay-at-home orders on the google mobility measures. These are potential indicators of the success of the stay-at-home in achieving social distancing as well as measuring the impact on the economy. Figure A1 shows the time series of the google mobility measures in the matched county border sample for places that eventually adopted stay-at-home versus those counties that had never adopted. There is significant correlation between the two series implying stay-at-home orders are not entirely driving individual reactions. Moreover, the time series show significant movement before stay-at-home orders were effective in both types of counties. The major declines for work and retail come around the days of 11-16 March. These are the dates around which many places announced school closures and limited public gatherings. The drops occur simultaneously in stay-at-home counties and places that never adopted these policies. This suggests people reacted to common information prior to policy implementation and to policies in other jurisdictions. 
Error! Reference source not found. Table A2 shows regression results. Figure 3 shows event study results for work and residential activity. Our regressions control for a quadratic time trend in event time, calendar day fixed effects and county pair fixed effects. Standard errors are clustered at the state and "border segment" level and we weight by county population. Un-reported results allow for a border-pair by day interaction term and results are highly similar in qualitative terms.

In our matched border sample, workplace, retail, transit, and park activity in counties with stay-at-home declined more than in those counties without stay-at-home. Residential activity increased more in counties with stay-at-home. The differences are not necessarily economically large being on the order of -2.48 percentage points for work (95\% C.I. -3.65 to -1.38 ) and 1.44 percentage points for residential activity (95\% C.I. 0.89 to 2.03). The mean values of the mobility indexes for work and residential were $-34 \%$ and $14.76 \%$ respectively by 18 March.

A large fraction of the drop in activity appears to be driven by a common shift downwards in mobility as indicated by the set of calendar day fixed effects. These common shifts preceded, or were coincident with, school closures and declarations of states of emergency. The day indicators for work mobility become consistently negative on 10 March (point estimate $-5.1, \mathrm{p}$-value $=0.004,95 \%$ C.I. -8.43 to -1.76 ) and fall strongly and monotonically so that by 19 March the common (conditional) shift as per the day indicators is at -45.33 percentage points ( $p$-value $=0.00095 \%$ C.I. -42.22 to -42.44 ). We have coded the dates of school closures or earlier implementations of NPIs such as limitation on dine-in restaurants; un-reported results show that these alternative dates for NPIs are statistically insignificant.

Figure 3 confirms that after stay-at-home policy implementation there is a differential impact on mobility between counties that have a stay-at-home policy and those that do not. These effects become larger over time. After 20 to 24 days, a county with stay-at-home has roughly 7 percent lower work "mobility" than a county without stay-at-home. There are also dynamics for residential activity. After 20 days, counties with stay-at-home are roughly 3.5 percentage points higher in terms of residential activity compared to non-stay-at-home counties. Retail activity using the Google mobility data also shows a strong decline in the stay-at-home counties relative to non-stay-at-home counties.

Overall, stay-at-home does seem to reduce workplace activity, induces people to stay near home, and reduces retail activity. Still, even though the magnitude of the relationships increase in absolute magnitude over time, they are a small fraction of the overall change. Compare the event study model predictions of a $7 \%$ drop in work mobility after twenty days to the average predicted decline of $35 \%$ or the $3.5 \%$ predicted increase in residential activity to the conditional rise of $14.76 \%$ cited above.

Pre-trends are also somewhat evident. Work mobility was somewhat higher and residential mobility lower in counties that eventually adopted stay-at-home in the weeks before the policy. It is hard to understand these pre-event trends, but anticipation of reduced 
mobility might have led people to inter-temporally substitute and work more prior to the onset of the stay-at-home policy. Our bottom line is that policy may have some impact on economic activity, as measured by Google mobility indexes, but common effects seem to have much larger effects. ${ }^{7}$

In Table 2 we show that (the logarithm of) state-level applications for unemployment insurance (i.e., jobless claims) rose more slowly (or at least no more strongly) in states that adopted stay-at-home policies as in states without stay-at-home. The point estimate is -0.309 ( $\mathrm{p}$-value $=0.10895 \%$ C.I. -0.675 to 0.069 ). Based on this, there is no evidence that stay-athome policies led to stronger rises in jobless claims. In un-reported results, we found that none of the mobility measures are significant determinants of initial jobless claims after including state and day fixed effects.

We also explore an event study for jobless claims and find that stay-at-home was associated with lower increases in unemployment with a lag. In columns 2 (not population weighted) and 3 (population weighted regressions) the association between stay at-home policies and jobless claims is statistically significant and negative two and three weeks after implementation. The coefficient on the first week is not highly statistically significant. We also use six leads of the indicators for stay-at-home. None of these leading marginal effects is statistically significant implying that pre-policy trends are unlikely to account for the postpolicy rises in initial jobless claims. In un-reported results we included controls for spillovers as in Table 1 . These are not statistically significant, and neither is the own state stay-at-home indicator.

In Table A2 we explore heterogeneous effects of stay-at-home by checking for a relationship between stay-at-home and industry-level employment-to-population shares for selected industries as well as an interaction for the share of jobs in a state that could be worked from home. ${ }^{8}$ We include separate effects for industries that are most likely to be done "in-person". For the main effects, we find jobless claims grew most strongly in states with higher shares of employment in the leisure and recreation industry and in wholesale distribution and were smaller where employment shares in retail were higher. There is little straightforward evidence linking stay-at-home to job losses in states with greater employment shares in occupations and industries at risk to social distancing and NPIs like in-person sectors such as retail, food and leisure.

Stay-at-home policy does have an intuitively smaller impact on job losses in proportion to the share of jobs that can be done from home. When we include a control for the share of jobs that can be done from home and an interaction effect with stay-at-home, the un-interacted stay-at-home main effect is associated with higher jobless claims with a

\footnotetext{
${ }^{7}$ If we run these event studies at the state level, we find that stay-at-home is associated with significantly lower work activity and significantly higher residential activity. The pre-policy trends are qualitatively similar. Results are similar for regressions with all counties with available data and not just contiguous counties.

${ }^{8}$ We also interact state-fixed effects with the stay-at-home policy which allows for heterogeneous impacts by state. The association between jobless claims and stay-at-home indeed varies by state. It is difficult to see a clear pattern here however.
} 
point estimate of 2.55 (p-value $=0.064,95 \%$ C.I. -0.159 to 5.27). However, the interaction with the share of jobs that can be worked from home is large and negative at -4.93 (p-value $=0.063,95 \%$ C.I. -10.15 to 0.28 ). The average share of jobs that can be worked from home is 0.38 implying that states above average and near the top of the distribution, at a share of about 0.48 , felt an impact on jobless claims from stay-at-home roughly $1 / 3$ as large as states at the mean. It appears that the impact of stay-at-home policies on the economy are also mitigated by the ability to work from home.

\section{Discussion and comment}

Stay-at-home, a relatively aggressive NPI, is only weakly associated with lower growth rates of confirmed cases of Covid-19. There is "spillover" of policies to geographically proximate units. When we use a matched sample of counties, the impact on growth of cases of covid-19 is not statistically significant. Variations in mobility are not associated with the growth rate of cases.

Stay-at-home is a significant determinant of mobility. However, behavioral responses and spillovers are highly relevant and much stronger predictors consistent with our other findings about the economy and policy. Mobility was affected strongly by common shocks associated with national awareness about the severity of the epidemic and as schools implemented and announced closures around 13 March.

On average, stay-at-home policies are not associated with higher joblessness in the US states that imposed them than in states that did not. We interpret this as evidence that the negative economic shocks were national and not local. There is however some evidence that stay-at-home has sectoral and occupational impacts. States with more jobs that can be done from home seem to have lost fewer jobs after implementing stay-at-home than states with fewer such jobs. This effect itself is not highly statistically significant.

Policy has been predicted to matter for the economy, at least in theory. We find no strong evidence of this in our sample. Stay-at-home is not the most economically important predictor of mobility and its local impact on joblessness is highly dependent on model specification.

During Covid-19, behavior induced by NPIs like stay-at-home appears to spillover across states in the US data. These spillovers could arise due to direct limitations on contact with infected individuals from other jurisdictions. However, it could also be because of a

common informational environment. We find evidence that policies in the first-moving states matter more for other states than policies from later-moving states. This implies that part of the impact is due to reaction to news in other states. Such news may indicate the severity of an outbreak or a pandemic leading to decreases in labor supply and reactive social distancing even without policies in the locality. 
Evidence Error! Reference source not found.is also consistent with the idea that policies transmit information to other jurisdictions without policies. Even weeks after implementation, the bulk of the change in mobility is still accounted for by common shocks. Reduced demand for other states' products and services from places with stay-at-home could spillover to states without policy too. State-to-state trade or shipment data would be required to verify and validate this channel.

The association between own-state/own-county policy and growth of new cases of Covid-19 is weakened once accounting for neighboring state policies. It is further weakened by using a control group of counties on the side of a border that has no stay-at-home policy. This does not imply that local policy is un-necessary or fruitless since we believe that behavior responds to neighbor state policy. This implies there is justification for policy coordination if the objective is to mitigate the spread of disease and to reduce mortality. Externalities imply coordination as per standard economic theory.

Our results show that the state of the global/national economy can shift the frontier that trades economic loss for lower mortality. Local policy loses traction on local economic and public health and makes it hard to empirically identify a local tradeoff between health and the economy. Both economy and public health are somewhat out of the control of local policy makers in a pandemic. A globally coordinated response may have more control over this potential tradeoff. In terms of conceptualizing policy in the midst of a pandemic and its relation to economic theory, it should be recognized that local tradeoffs are very different from macro/economy wide tradeoffs.

During the re-opening process, results are likely to depend strongly on how public health and the economy evolve in other jurisdictions. However, this process is likely follow different dynamics than those outlined here (but in reverse) due to the changing nature of testing and tracing, population immunity developments, changes in expectations, as well as other significant policy changes at the national level. 


\section{References}

Acemoglu, D. Chernozhukov, V., Werning, I. and Whinston, M. D. 2020 A Multi-Risk SIR Model with Optimally Targeted Lockdown NBER WP 27102.

Adda, J., 2016. Economic activity and the spread of viral diseases: Evidence from high frequency data. The Quarterly Journal of Economics, 131(2), pp.891-941.

Andersen, A.L., Hansen, E.T., Johannesen, N. and Sheridan, A. 2020. Pandemic, Shutdown and Consumer Spending: Lessons from Scandinavian Policy Responses to COVID-19. Mimeo University of Copenhagen.

Baker, S.R., Farrokhnia, R.A., Meyer, S., Pagel, M. and Yannelis, C., 2020. How Does Household Spending Respond to an Epidemic? Consumption During the 2020 Covid-19 Pandemic (No. w26949). National Bureau of Economic Research

Baldwin, R. 22 March 2020. The supply side matters: Guns versus butter, COVID-style VoxEU downloaded on 11 April, 2020 https://voxeu.org/article/supply-side-matters-guns-versus-buttercovid-style

Barro, R. Non-Pharmaceutical Interventions and Mortality in U.S. Cities during the Great Influenza Pandemic, 1918-1919. NBER WP 27049.

Barro, R.J., Ursúa, J.F. and Weng, J., 2020. The coronavirus and the great influenza pandemic: Lessons from the "spanish flu" for the coronavirus's potential effects on mortality and economic activity (No. w26866). National Bureau of Economic Research.

Beck, T. and Wagner, W. 2020 National containment policies and international cooperation. Covid Economics 22 April 2020 CEPR Press.

Courtemanche, C. Garuccio, J., Le, A. Pinkston, J. and Yelowitz, A. 2020 "Strong Social Distancing Measures In The United States Reduced The COVID-19 Growth Rate" Health Affairs. Published online 5/19/2020. https://doi.org/10.1377/hlthaff.2020.00608.

Correia, S., Luck, S. and Verner, E., 1918. Pandemics Depress the Economy, Public Health Interventions Do Not: Evidence from the 1918 Flu. Public Health Interventions Do Not: Evidence from the 1918 flu. Mimeo MIT.

Bootsma, M.C. and Ferguson, N.M., 2007. The effect of public health measures on the 1918 influenza pandemic in US cities. Proceedings of the National Academy of Sciences, 104(18), pp.7588-7593.

Dave, D., Friedson, A., Matsuzawa, K. and Sabia, J. J. 2020. When Do Shelter-in-Place Orders Fight COVID-19 Best? Policy Heterogeneity Across States and Adoption Time. NBER WP 27091.

Dingel, J.I. and Neiman, B., 2020. Who can work from home? Covid Economics Vol. 1. pp. 16-24.

Dube, A., Lester, T.W. and Reich, M., 2010. Minimum wage effects across state borders: Estimates using contiguous counties. The review of economics and statistics, 92(4), pp.945-964.

Eichenbaum, M.S., Rebelo, S. and Trabandt, M., 2020. The macroeconomics of epidemics (No. w26882). National Bureau of Economic Research. 
Gourinchas, Pierre-Olivier 2020. Flattening the pandemic and recession curves, Chapter 2 in $\mathrm{R}$ Baldwin and B Weder di Mauro (eds), Mitigating the COVID economic crisis: Act fast and do whatever it takes, a VoxEU.org eBook, CEPR Press.

Hatchett, R.J., Mecher, C.E. and Lipsitch, M., 2007. Public health interventions and epidemic intensity during the 1918 influenza pandemic. Proceedings of the National Academy of Sciences, 104(18), pp.7582-7587.

Kahn, L.B., Lange, F. and Wiczer, D.G. 2020. "Labor Demand in the time of Covid-19: Evidence from Vacancy Postings and Claims” NBER WP 27061.

Jordà, O., Singh, S.R. and Taylor, A.M., 2020. "Longer run economic consequences of pandemics. Covid Economics vol. 1. pp. 1-15.

Krueger, D. Uhlig, H. and Xie, Taojun. 2020 Macroeconomic dynamics and reallocation in an epidemic Covid Economics 16 April 2020 CEPR Press.

Markel, H., Lipman, H.B., Navarro, J.A., Sloan, A., Michalsen, J.R., Stern, A.M. and Cetron, M.S., 2007. Nonpharmaceutical interventions implemented by US cities during the 1918-1919 influenza pandemic JAMA, 298(6), pp.644-654.

Mervosh, S. Lu, D. and Swales, V. 2020. See Which States and Cities Have Told Residents to Stay-at-home New York Times downloaded on 5 May from https://www.nytimes.com/interactive/2020/us/coronavirus-stay-at-home-order.html 
Table 1 Change in (log) Confirmed Cases versus Stay-at-Home Orders and Neighboring States' Stay-at-Home Policies.

\begin{tabular}{|c|c|c|c|c|}
\hline & $(1)$ & $(2)$ & (3) & (4) \\
\hline \multirow{2}{*}{$S_{i}=$ Stay-at-home } & $-0.0285^{* *}$ & $-0.0216^{*}$ & $-0.0226^{*}$ & $-0.0217^{*}$ \\
\hline & $(0.0124)$ & $(0.0116)$ & $(0.0116)$ & $(0.0118)$ \\
\hline \multirow[t]{2}{*}{$S_{i,-i}=($ Stay-at-home $-\mathrm{i}) \mathrm{x}$ week ending 21 Mar. } & & -2.364 & -5.189 & -6.528 \\
\hline & & $(3.862)$ & $(5.449)$ & $(7.859)$ \\
\hline \multirow[t]{2}{*}{$S_{i,-i}=($ Stay-at-home $-\mathrm{i}) \mathrm{x}$ week ending 28 Mar. } & & $-2.102^{* *}$ & $-3.094^{* * *}$ & $-3.324^{* * *}$ \\
\hline & & $(0.945)$ & $(1.057)$ & $(1.196)$ \\
\hline \multirow[t]{2}{*}{$S_{i,-i}=($ Stay-at-home-i $) \mathrm{x}$ week ending 4 Apr. } & & $-1.937^{* *}$ & $-2.029^{*}$ & $-2.219^{*}$ \\
\hline & & $(0.934)$ & $(1.018)$ & $(1.122)$ \\
\hline \multirow[t]{2}{*}{$S_{i,-i}=($ Stay-at-home $-\mathrm{i}) \mathrm{x}$ week ending $11 \mathrm{Apr}}$. & & -1.185 & -1.247 & -1.468 \\
\hline & & $(0.934)$ & $(1.007)$ & $(1.123)$ \\
\hline \multirow[t]{2}{*}{$S_{i,-i}=\left(\right.$ Stay-at-home $\left.{ }_{-\mathrm{i}}\right) \mathrm{x}$ week ending $18 \mathrm{Apr}}$. & & -1.149 & -1.267 & -1.506 \\
\hline & & $(0.808)$ & $(0.881)$ & $(1.052)$ \\
\hline \multirow[t]{2}{*}{$S_{i,-i}=($ Stay-at-home $-\mathrm{i}) \mathrm{x}$ week ending $25 \mathrm{Apr}$. } & & -1.013 & -1.220 & -1.453 \\
\hline & & $(0.800)$ & $(0.875)$ & $(1.062)$ \\
\hline \multirow[t]{2}{*}{$S_{i,-i}^{\prime}=$ (Stay-at-home- border states) $\mathrm{x}$ week ending $21 \mathrm{Mar}$. } & & & 0.0316 & 0.0339 \\
\hline & & & $(0.0409)$ & $(0.0427)$ \\
\hline \multirow[t]{2}{*}{$S_{i,-i}^{\prime}=$ (Stay-at-home- border states) $\mathrm{x}$ week ending $28 \mathrm{Mar}$. } & & & $0.0107^{* *}$ & $0.0111^{* *}$ \\
\hline & & & $(0.00523)$ & $(0.00535)$ \\
\hline \multirow[t]{2}{*}{$S_{i,-i}^{\prime}=$ (Stay-at-home- border states) $\mathrm{x}$ week ending $24 \mathrm{Mar}$. } & & & 0.00109 & 0.00183 \\
\hline & & & $(0.00518)$ & $(0.00602)$ \\
\hline \multirow[t]{2}{*}{$S_{i,-i}^{\prime}=$ (Stay-at-home- border states) $\mathrm{x}$ week ending $11 \mathrm{Apr}$. } & & & 0.000486 & 0.00122 \\
\hline & & & $(0.00644)$ & $(0.00734)$ \\
\hline \multirow[t]{2}{*}{$S_{i,-i}^{\prime}=$ (Stay-at-home- border states) x week ending $18 \mathrm{Apr}$. } & & & 0.00188 & 0.00261 \\
\hline & & & $(0.00590)$ & $(0.00682)$ \\
\hline \multirow[t]{2}{*}{$S_{i,-i}^{\prime}=$ (Stay-at-home- border states) $\mathrm{x}$ week ending $25 \mathrm{Apr}$. } & & & 0.00403 & 0.00477 \\
\hline & & & $(0.00601)$ & $(0.00693)$ \\
\hline \multirow[t]{2}{*}{ ln (confirmed cases-i/distance) } & & & & 0.00224 \\
\hline & & & & $(0.0369)$ \\
\hline \multirow[t]{2}{*}{ ln (confirmed cases, border states) } & & & & 0.0117 \\
\hline & & & & $(0.0394)$ \\
\hline Observations & 2442 & 2442 & 2442 & 2442 \\
\hline \multirow{2}{*}{$\begin{array}{l}\mathrm{R}^{2} \\
\text { States }\end{array}$} & 0.380 & 0.383 & 0.384 & 0.385 \\
\hline & 49 & 49 & 49 & 49 \\
\hline Week Dummies & YES & YES & YES & YES \\
\hline
\end{tabular}

Notes: Dependent variable is the daily change in the logarithm of confirmed cases of Covid-19 at the state level. Estimation is by OLS. All models include state fixed effects. Event time trend and a quadratic term in event time are included. Event time is defined as number of days since the first official case of Covid-19. Week indicators for all weeks after the week ending 28 March are included. All regressions are weighted by state population. Standard errors in parentheses are clustered at the state level.

$* \mathrm{p}<0.1,{ }^{* *} \mathrm{p}<0.05,{ }^{* * *} \mathrm{p}<0.01$. 
Table 2 Initial jobless claims and the Dynamics of Own-State Stay-at-Home Orders: StateLevel Data
(1)
(2)
(3)

\begin{tabular}{|c|c|c|c|}
\hline Stay-at-home & $\begin{array}{l}-0.309^{*} \\
(0.179)\end{array}$ & & \\
\hline Stay-at-home (3 weeks after) & & $\begin{array}{c}-0.629^{* * *} \\
(0.230)\end{array}$ & $\begin{array}{c}-0.494^{* * *} \\
(0.164)\end{array}$ \\
\hline Stay-at-home (2 weeks after) & & $\begin{array}{c}-0.427^{* *} \\
(0.166)\end{array}$ & $\begin{array}{c}-0.398^{* * *} \\
(0.121)\end{array}$ \\
\hline Stay-at-home (initial week) & & $\begin{array}{c}-0.304 \\
(0.188)\end{array}$ & $\begin{array}{c}-0.166^{* *} \\
(0.0782)\end{array}$ \\
\hline Stay-at-home ( 2 weeks before) & & $\begin{array}{c}-0.00315 \\
(0.124)\end{array}$ & $\begin{array}{c}-0.00453 \\
(0.122)\end{array}$ \\
\hline Stay-at-home ( 3 weeks before) & & $\begin{array}{c}-0.0176 \\
(0.0907)\end{array}$ & $\begin{array}{l}0.0286 \\
(0.105)\end{array}$ \\
\hline Stay-at-home ( 4 weeks before) & & $\begin{array}{l}0.0356 \\
(0.117)\end{array}$ & $\begin{array}{c}0.0409 \\
(0.0853)\end{array}$ \\
\hline Stay-at-home (5 weeks before) & & $\begin{array}{c}-0.0400 \\
(0.0509)\end{array}$ & $\begin{array}{r}-0.00228 \\
(0.0651)\end{array}$ \\
\hline Stay-at-home (6 weeks before) & & $\begin{array}{l}-0.0658^{*} \\
(0.0385)\end{array}$ & $\begin{array}{c}-0.0571 \\
(0.0448)\end{array}$ \\
\hline$N$ & 459 & 459 & 459 \\
\hline Number of States $+D C$ & 51 & 51 & 51 \\
\hline $\mathrm{R}^{2}$ & 0.975 & 0.976 & 0.977 \\
\hline
\end{tabular}

Notes: Dependent variable is the logarithm of initial jobless claims in the previous week (not seasonally adjusted). Estimation is by OLS. Data is a panel of states + District of Columbia by week. All models include state fixed effects and calendar week fixed effects. Regressions (1) and (2) are weighted by state population. Column (3) is an unweighted regression. In columns (2) and (3) week $t$ is the first week for the stay-at-home order. Week $\mathrm{t}-3$ denotes three weeks after stay-at-home was initiated, $\mathrm{t}-2$ two week etc. The week prior to initiation of the stay-at-home order is the reference group. Standard errors in parentheses are clustered at the country level. ${ }^{*} p<0.1,{ }^{* *} p<0.05,{ }^{* * *} p<0.01$ 
Figure 1 Stay-at-Home and the Growth Rate of Cumulative Cases of Covid-19: Event Study State-Level Data

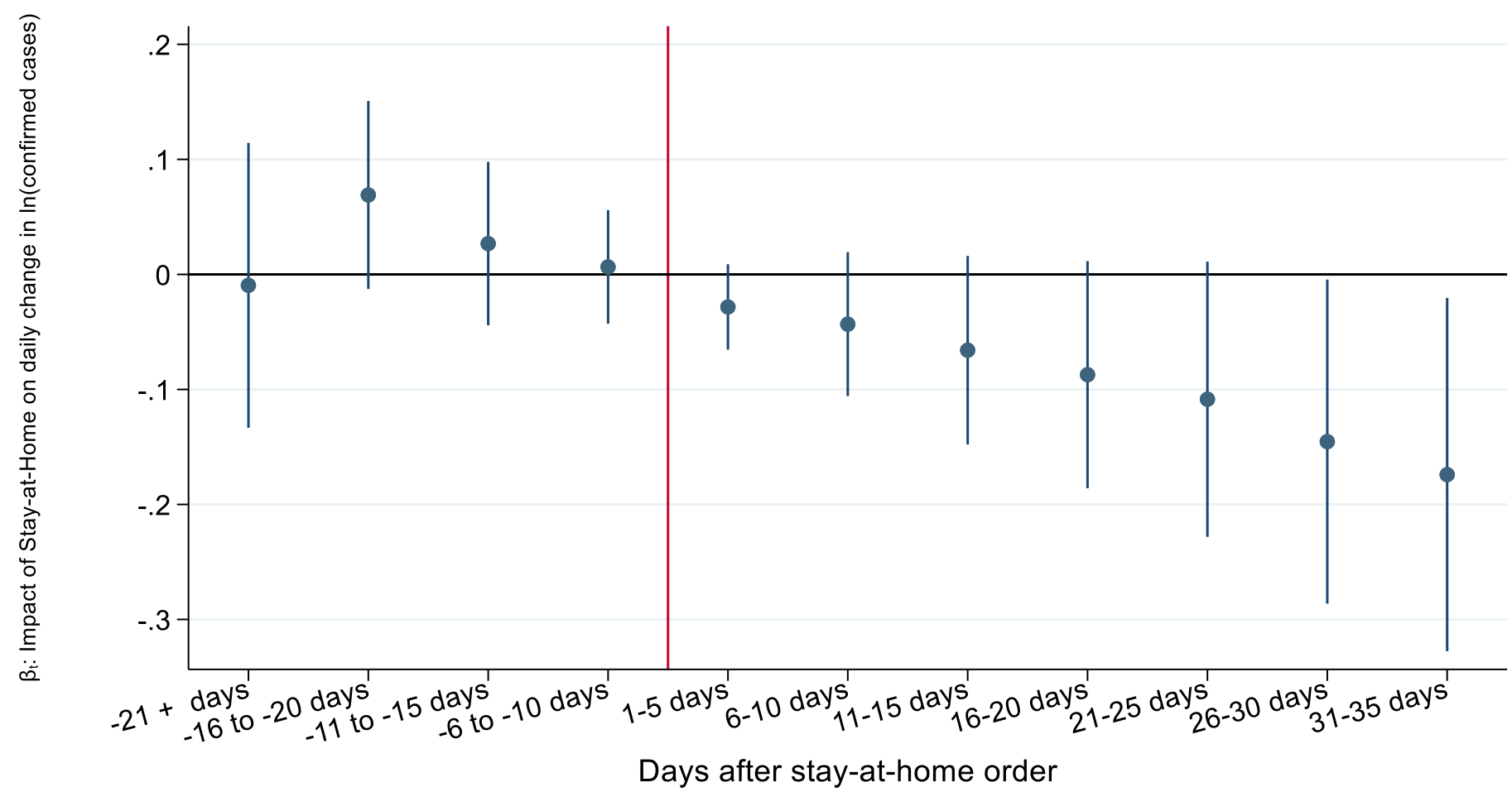

Notes: Chart shows the average impact of stay-at-home on the daily change in the log of confirmed cases of Covid-19 in periods before and after implementing a stay-at-home order with $95 \%$ confidence bars. The levels (dots) are the coefficients from OLS regressions where the dependent variable is the daily change in the logarithm of confirmed cases. Regressions include state fixed effects, event time trend and quadratic effect and calendar day dummies. Event time is counted in days since the first case of Covid-19 within a state. Data are for 1 March, 2020 through 25 April, 2020. Standard errors are clustered at the state level. 
Figure 2 Growth of Cumulative Covid-19 Cases and Stay-at-Home Orders: Matched Border Pair Sample

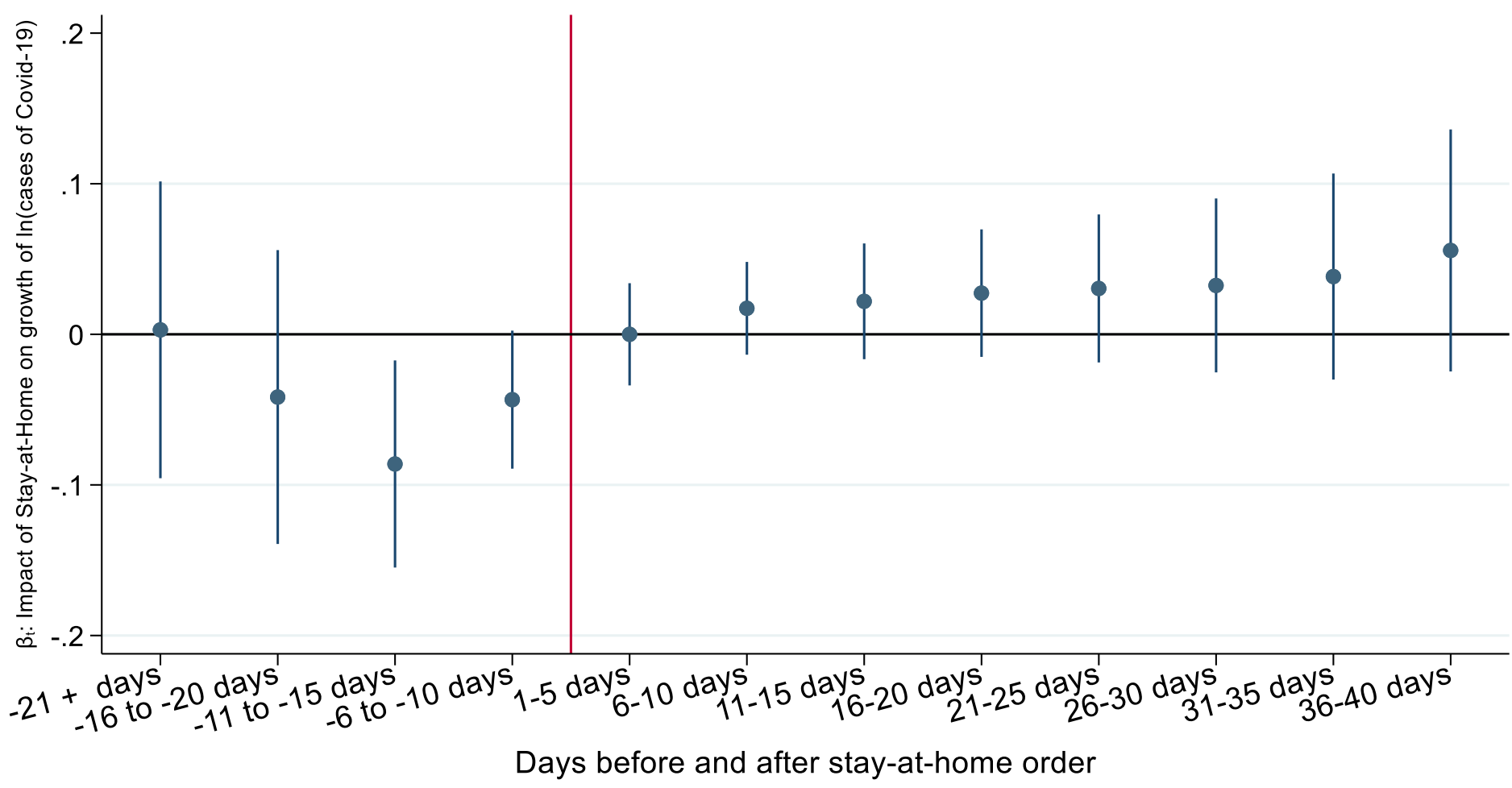

Notes: Figure shows coefficients from a regression of the daily change in the logarithm of total Covid-19 cases at the county level on a stay-at-home indicator. The omitted category of the day of implementation of stay-athome. The regression includes an event time trend and the square of event time. Regression is weighted by county population. Event days count the number of days since the first reported case in the county. The sample is for a balanced panel of matched border counties (see Figure A1). Data are for 1 March 2020 to 25 April, 2020 We also include county-pair and calendar date fixed effects. Standard errors are clustered at the state and "border segment". 95\% confidence bands are presented. The vertical line is the day the stay-at home order is implemented. 
Figure 3 Google "Mobility" Report for Workplaces and Residential Activity vs Stay-at-home Orders: Matched Border Pair Sample
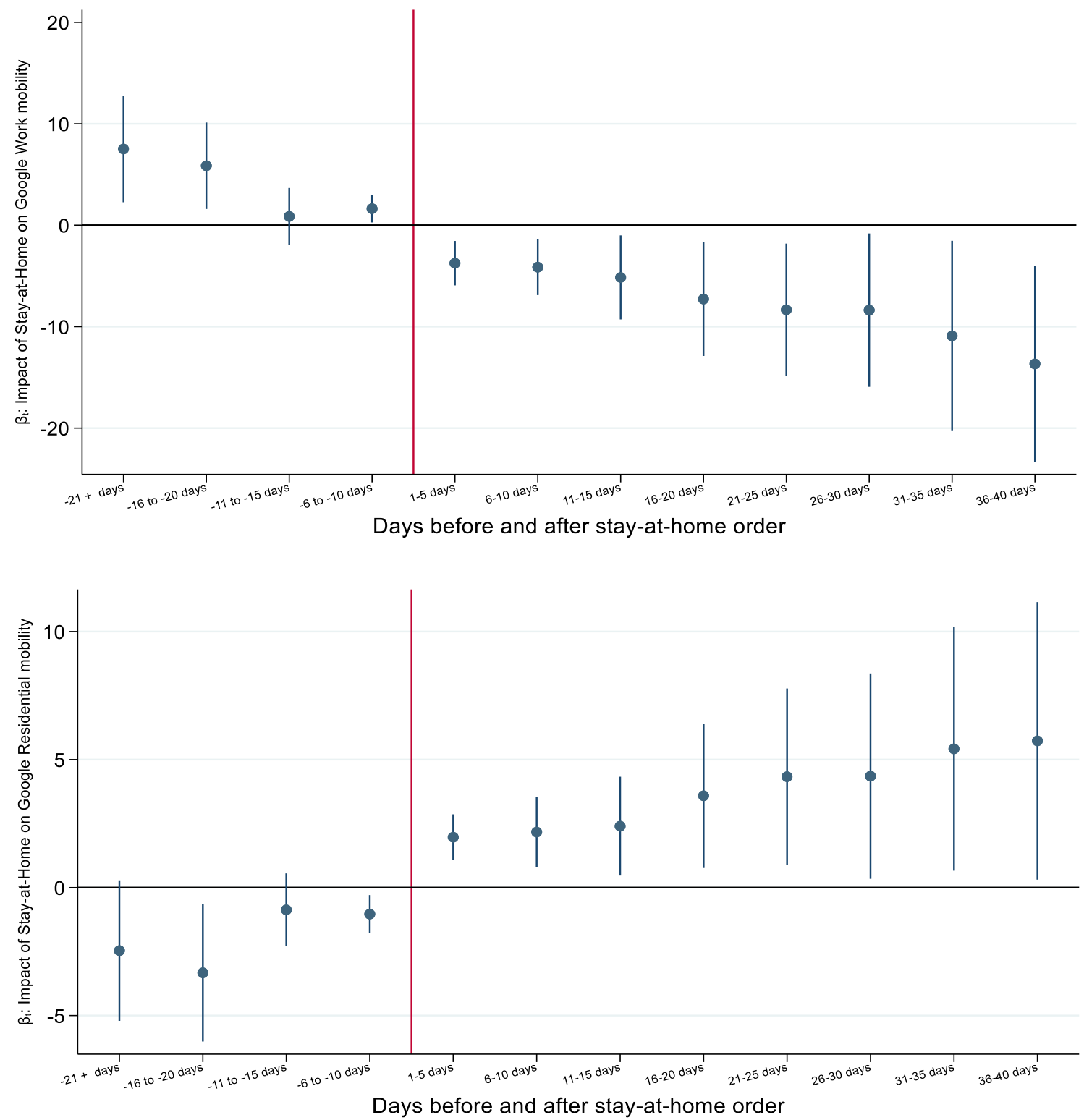

Notes: Figures show coefficients from a regression of the percentage deviation from "baseline" of the Google workplace mobility and residential activity data versus the county level stay-at-home indicator. The omitted category of the day of implementation of stay-at-home. The regressions include event time trends and the square of event time. Event days count the number of days since the first reported case in the county. The sample is for a balanced panel of matched border counties (see Figure A1). Data are for 1 March 2020 to 25 April, 2020 We also include county-pair and calendar date fixed effects. Standard errors are clustered at the state and "border segment". 95\% confidence bands are presented. The vertical line is the period when the stayat home order is implemented. 


\section{Appendix: Supplemental Results}

Table A1 Daily Change in the log of Total Covid-19 Cases vs Google Mobility: Matched Border Counties Sample

(1)

(2)

(3)

(4)

(5)

(6)

Retail

$-0.00138^{*}$

$(0.000750)$

Grocery

$-0.000140$

(0.000294)

Parks

$-0.0000884$

$(0.0000811)$

Transit

$-0.000843^{* *}$

$(0.000333)$

Work

$-0.00124$

(0.000825)

Residential

0.00254

$(0.00185)$

\begin{tabular}{lllllll}
\hline$N$ & 6068 & 6068 & 6068 & 6068 & 6068 & 6068 \\
$R^{2}$ & 0.183 & 0.180 & 0.180 & 0.183 & 0.181 & 0.181 \\
\hline
\end{tabular}

Notes: Dependent variable is daily change in the logarithm of the county cumulative cases of Covid-19. The key independent variable is the deviation of one Google's six mobility measures from its baseline. Regressions are for a matched border pair sample of US counties. The sample runs form March 1 until 25 April. Regressions include a countypair fixed effect and calendar day dummies. All regressions are weighted by county population. Standard errors in parentheses are clustered at the state and "border segment" level. ${ }^{*} \mathrm{p}<0.1,{ }^{* *} \mathrm{p}<0.05,{ }^{* * *} \mathrm{p}<0.01$ 
Table A2 Google Mobility Measures versus Stay-at-Home Orders: Matched Border Counties Sample

\begin{tabular}{lcccccc}
\hline & $(1)$ & $(2)$ & $(3)$ & $(4)$ & $(5)$ & $(6)$ \\
& Retail & Grocery & Parks & Transit & Work & Residential \\
\hline Stay-at-home & $-3.644^{* * * *}$ & $-4.649^{* * *}$ & $-14.71^{* * *}$ & $-3.943^{* * *}$ & $-2.483^{* * * *}$ & $1.444^{* * *}$ \\
& $(1.150)$ & $(1.057)$ & $(3.463)$ & $(1.302)$ & $(0.565)$ & $(0.283)$ \\
Event time & & & & & \\
& 0.0104 & $-0.0456^{*}$ & $-0.240^{* *}$ & $-0.112^{* *}$ & $-0.0513^{*}$ & 0.00706 \\
& $(0.0323)$ & $(0.0233)$ & $(0.103)$ & $(0.0447)$ & $(0.0293)$ & $(0.0100)$ \\
$(\text { Event time) })^{2}$ & & & & & & \\
& -0.0000319 & $0.000135^{* *}$ & 0.000511 & $0.000304^{* * *}$ & $0.000106^{*}$ & -0.00000703 \\
& $(0.000104)$ & $(0.0000654)$ & $(0.000425)$ & $(0.0001000)$ & $(0.0000577)$ & $(0.0000211)$ \\
\hline$N$ & 6068 & 6068 & 6068 & 6068 & 6068 & 6068 \\
$R^{2}$ & 0.862 & 0.794 & 0.513 & 0.751 & 0.904 & 0.909 \\
\hline
\end{tabular}

Notes: Dependent variable is deviation of one Google's six mobility measures from its baseline (see data appendix). Regressions are for a matched border pair sample of 150 US counties. The sample runs form March 1 until 25 April. Regressions include county-pair fixed effects and calendar day dummies. Event time is defined as the number of days since the first official case at the county level. All regressions are weighted by county population. Standard errors in parentheses are clustered at the state and "border segment" level. ${ }^{*} \mathrm{p}<0.1,{ }^{* *} \mathrm{p}<0.05,{ }^{* * *} \mathrm{p}<0.01$ 
Table A3 Initial jobless claims, Stay-at-Home Orders and Sectoral Employment: State-Level Data

\begin{tabular}{|c|c|c|c|c|}
\hline & (1) & $(2)$ & (3) & $(4)$ \\
\hline Stay-at-home & $\begin{array}{l}-0.303 \\
(0.185)\end{array}$ & $\begin{array}{c}0.537 \\
(0.367)\end{array}$ & $\begin{array}{c}2.403^{*} \\
(1.355)\end{array}$ & $\begin{array}{c}2.559^{*} \\
(1.353)\end{array}$ \\
\hline Average Share of Jobs-at-home & & $\begin{array}{c}4.644 \\
(3.689)\end{array}$ & $\begin{array}{c}6.315 \\
(3.974)\end{array}$ & $\begin{array}{l}0.0706 \\
(4.373)\end{array}$ \\
\hline Stay-at-home x Average Share of Jobs-at-home & & & $\begin{array}{l}-4.927 \\
(3.559)\end{array}$ & $\begin{array}{l}-4.937^{*} \\
(2.599)\end{array}$ \\
\hline Share of Jobs in Oil \& Gas & & & & $\begin{array}{c}55.43 \\
(169.0)\end{array}$ \\
\hline Share of Jobs in Arts, Rec. and Entertainment & & & & $\begin{array}{l}255.8^{* * *} \\
(86.32)\end{array}$ \\
\hline Share of Jobs in Food \& Accommodation & & & & $\begin{array}{l}-10.73 \\
(17.72)\end{array}$ \\
\hline Share of Jobs in Retail & & & & $\begin{array}{l}-189.4^{* * *} \\
(38.91)\end{array}$ \\
\hline Share of Jobs in Wholesale & & & & $\begin{array}{l}149.9^{* * *} \\
(41.93)\end{array}$ \\
\hline Share of Jobs in Oil \& Gas x Stay-at-home & & & & $\begin{array}{l}-316.3^{* * *} \\
(89.42)\end{array}$ \\
\hline $\begin{array}{l}\text { Share of Jobs in Arts, Rec. and Entertainment x Stay- } \\
\text { at-home }\end{array}$ & & & & $\begin{array}{l}-124.7^{* *} \\
(55.04)\end{array}$ \\
\hline $\begin{array}{l}\text { Share of Jobs in Food \& Accommodation x Stay-at- } \\
\text { home }\end{array}$ & & & & $\begin{array}{l}-2.579 \\
(10.13)\end{array}$ \\
\hline Share of Jobs in Retail x Stay-at-home & & & & $\begin{array}{c}9.512 \\
(17.31)\end{array}$ \\
\hline Share of Jobs in Wholesale $x$ Stay-at-home & & & & $\begin{array}{c}-6.138 \\
(27.31)\end{array}$ \\
\hline $\begin{array}{l}N \\
R^{2}\end{array}$ & $\begin{array}{c}267 \\
0.971\end{array}$ & $\begin{array}{c}267 \\
0.662\end{array}$ & $\begin{array}{c}267 \\
0.663\end{array}$ & $\begin{array}{c}267 \\
0.849\end{array}$ \\
\hline
\end{tabular}

Notes: Dependent variable is the log of initial jobless claims (not seasonally adjusted). Estimation is by OLS. Data is a panel of states + District of Columbia by week. Column (1) includes state fixed effects and all models have calendar week fixed effects. Regressions are weighted by state population. Standard errors in parentheses are clustered at the state level. ${ }^{*} p<0.1{ }^{* *} p<$ $0.05,{ }^{* * *} p<0.01$ 
Figure A1 Google Mobility Measures for Stay-at-Home vs non-Stay-at-Home: Matched Border County Sample
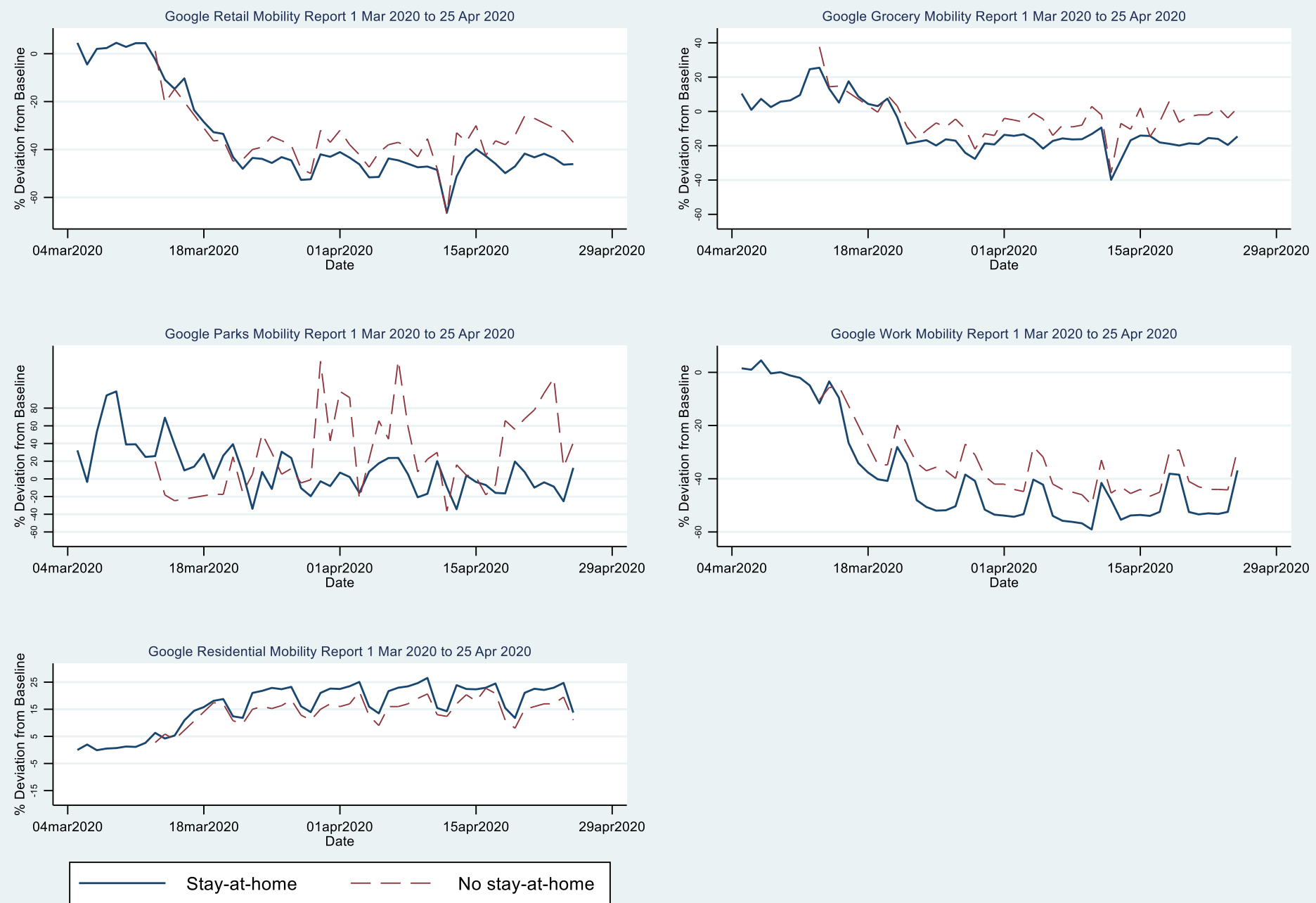

Notes: Figures show the population weighted average for various google mobility measures by "stay-at-home" status. The sample is for 1 March 2020 to 25 April 2020. The sample is the matched border county pair sample in Figure A2. Dashed lines are for counties that never adopted "stay-at-home" in the sample and solid lines are for counties in states that did adopt stay-at-home at some point after 1 March. Averages are weighted by county population. 


\section{Data Appendix for "Health vs Wealth? Public Health Policies and the Economy During The Covid-19 Pandemic"}

\section{Covid-19 Data, Confirmed Cases and Deaths by Country and US state and territory, January-April 2020}

The data of confirmed cases and deaths of Covid-19 across countries are from the Center for Systems Science and Engineering (CSSE) in Johns Hopkins University and represent a compilation of data reported by the WHO or the official reports from countries' public health authorities. Daily updates can be downloaded from:

https://github.com/CSSEGISandData/COVID19/tree/master/csse covid 19 data/csse covid 19 daily reports

The state-level cumulative counts of coronavirus cases and deaths in the United States are compiled by The New York Times and are originally from the state and local governments and health departments. Data begins with the first reported case in Washington state on Jan.21, 2020. Details on the daily updated database can be found:

https://github.com/nytimes/covid-19-data

\section{Non-pharmaceutical interventions (NPI) data - Stay-at-home}

The information of stay-at-home orders placed by U.S. states are from the public orders and announcements made by the state governments or public health authorities. The timing of these orders being effective is compiled by the New York Times (Mervosh, Lu, and Swales, 2020).

Details can be found:

https://www.nytimes.com/interactive/2020/us/coronavirus-stay-at-home-order.html

Data appendix 2 has more information on county and state level stay-at-home orders and other NPIs.

\section{DOL Initial jobless claims:}

Initial jobless claims are processed weekly on Thursdays and refer to claims from the previous week ending Saturday. We use the latest revisions available. 
These are available at

https://oui.doleta.gov/unemploy/claims.asp

\section{Employment in Mining, Quarrying, and Oil and Gas Extraction}

US Bureau of Labor Statistics. "OES Research Estimates by State and Industry" all occupations.

Downloaded from https://www.bls.gov/oes/current/oes research estimates.htm https://www.bls.gov/oes/current/oes research estimates.htm on 4/7/2020

We divide total employment in an industry by total population in a state. Industries for employment

Mining, Quarrying, and Oil and Gas Extraction, NAICS 21

Wholesale Trade, NAICS 42

Retail Trade, NAICS 44-45

Arts, Entertainment, and Recreation, NAICS 71

Accommodation and Food Services, NAICS 72

\section{Share of Jobs that can be done from home}

Dingel and Neiman (2020).

Data downloaded from github https://github.com/idingel/DingelNeimanworkathome

For MSAs spanning state borders we simply use the total employment weight given by total MSA employment in an MSA relative to employment in all other within state MSAs including this cross-state MSA.

\section{Employment by MSA}

https://www.bls.gov/web/metro.supp.toc.htm 
Data file is ssamattab.zip. We use total employment for February 2020 to weight the telecommuting index from Dingel and Neiman and to find a state-level weighted average.

\section{Matched Border Pair Sample}

We have 113 border pairs and 150 unique counties (some counties are in more than one pair). The map below shows the counties in our balanced, matched sample. The sample size is reduced because we require all Google mobility data and Covid-19 case data to be nonmissing for the period between 1 March 2020 and 25 April. Some counties did not report at least one case on or before 1 March 2020 in which case they are not included.

Figure A2 Map of Counties in the Matched Border Pair Sample

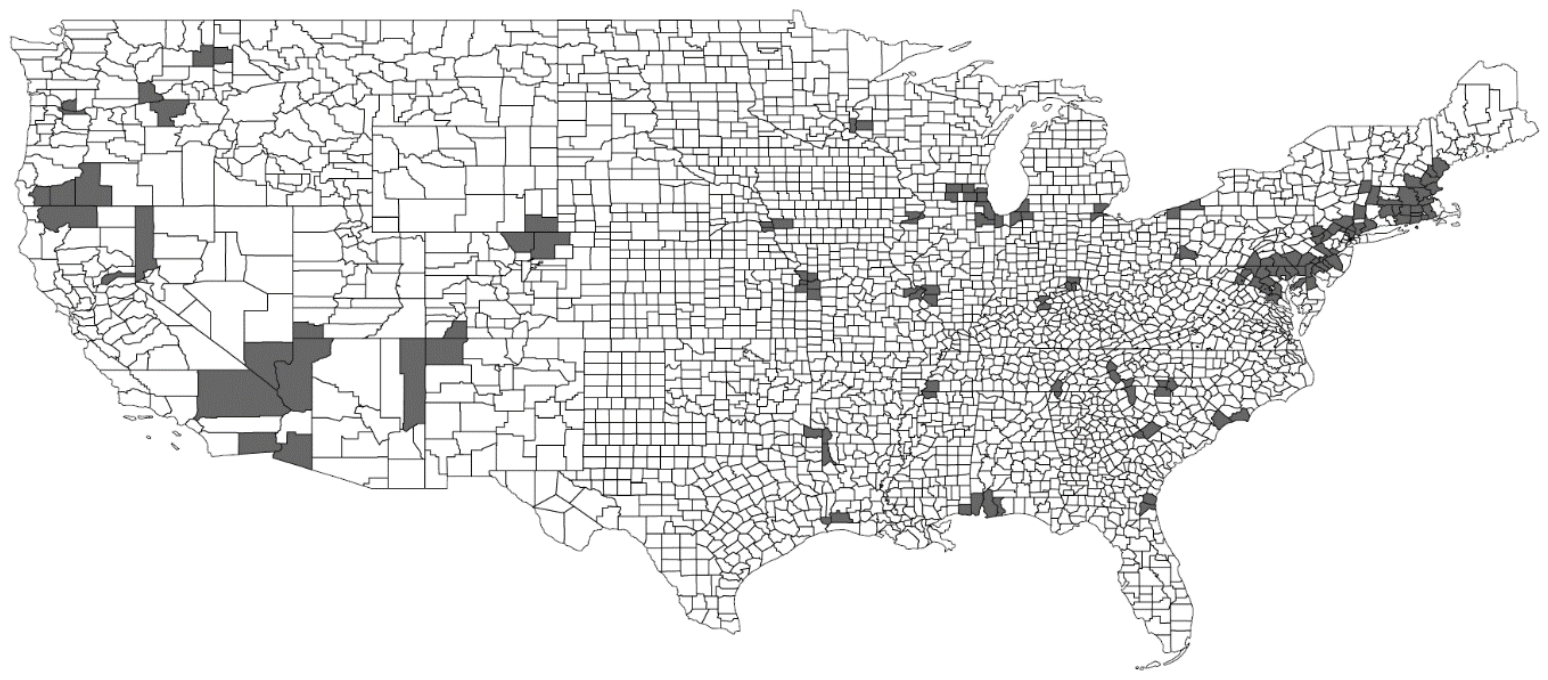




\section{Mobility Data}

Data downloaded from on 11 May, 2020: https://www.google.com/covid19/mobility/

Data are provided by Google. The description of the data from Google is as follows (abridged): these data "...chart movement trends over time by geography, across different categories of places such as retail and recreation, groceries and pharmacies, parks, transit stations, workplaces, and residential. Each Community Mobility Report dataset is presented by location and highlights the percent change in visits to places like grocery stores and parks within a geographic area... These datasets show how visits and length of stay at different places change compared to a baseline.... Changes for each day are compared to a baseline value for that day of the week. The baseline is the median value, for the corresponding day of the week, during the 5-week period Jan 3-Feb 6, 2020. 


\section{Data Appendix A2 \\ County and State Level "Stay-at-Home" Orders and other Non-Pharmaceutical Interventions (NPIs).}

This data appendix lists some dates for implementation of various NPIs at the county level. We list information and contemporary sources for these counties for policies such as school closures, limitations on public gatherings above certain sizes $(500,50$, or 10 were common numbers) and orders to stop dining-in at restaurants, working out at gyms and gambling at casinos. These cover the vast majority of NPIs implemented in these counties. These data are used in our matched county pair sample. We use the date of the country stay-at-home order if any is noted, otherwise we code the state level stay-at-home date. We also coded a date for earlier implementation of NPIs (usually school closures) and use these dates for robustness.

It is interesting to note that many counties took action earlier than at the state level and before national CDC guidance on NPIs. Other information was important too. On 11 March the NBA canceled its season and President Trump banned travel from Europe. Italy had gone into lockdown by 10 March. Many counties and school districts had decided to close public schools by 13 March and these decisions were often effective on 16 March. At the same time, or in the days surrounding these changes, most counties prohibited dining-in at restaurants and limited the size of public gatherings. School closures were often initially temporary but within one to three weeks were made permanent for the entire remainder of the school year. Connecticut implemented a "containment area" on 10 March.

The first counties to adopt shelter in place in the US were in the Bay Area of Northern California. These occurred on 17 March. Many other counties were contemplating these types of policies around the same time. The first state in the continental US to implement a state-wide stay-at-home was California on 19 March.

\section{Main sources for state level policies}

https://www.nytimes.com/interactive/2020/us/coronavirus-stay-at-homeorder.html

\section{School Closures List}

https://www.edweek.org/ew/section/multimedia/map-coronavirus-and-schoolclosures.html

https://ballotpedia.org/School closures in response to the coronavirus (COVID19) pandemic, 2020 


\section{List of states and their date for stay-at-home orders or other NPIs}

\begin{tabular}{lll} 
State & Date & action \\
\hline Alabama & $5-A p r-20$ & Stay-at-home \\
Alaska & $3 / 28 / 2020$ & Stay-at-home \\
Arizona & $3 / 31 / 2020$ & Stay-at-home \\
California & $3 / 19 / 2020$ & Stay-at-home \\
Colorado & $3 / 26 / 2020$ & Stay-at-home \\
Connecticut & $3 / 23 / 2020$ & Stay-at-home \\
Delaware & $3 / 24 / 2020$ & Shelter in Place \\
District of Columbia & $4 / 1 / 2020$ & Stay-at-home \\
Florida & $4 / 3 / 2020$ & Stay-at-home \\
Georgia & $4 / 3 / 2020$ & Shelter in Place \\
Hawaii & $3 / 25 / 2020$ & Stay-at-home \\
Idaho & $3 / 25 / 2020$ & Stay-at-home \\
Illinois & $3 / 21 / 2020$ & Stay-at-home \\
Indiana & $3 / 24 / 2020$ & Stay-at-home \\
Kansas & $3 / 30 / 2020$ & Stay-at-home \\
Kentucky & $3 / 23 / 2020$ & Healthy at Home \\
Louisiana & $3 / 23 / 2020$ & Stay-at-home \\
Maine & $4 / 2 / 2020$ & Stay-at-home \\
Maryland & $3 / 20 / 2020$ & Stay-at-home \\
Massachusetts & $3 / 24 / 2020$ & Stay-at-home \\
Michigan & $3 / 24 / 2020$ & Stay-at-home \\
Minnesota & $3 / 27 / 2020$ & Stay-at-home \\
Mississippi & $4 / 3 / 2020$ & Shelter in Place \\
Missouri & $4 / 6 / 2020$ & Stay-at-home \\
Montana & $3 / 28 / 2020$ & Stay-at-home \\
Nevada & $4 / 1 / 2020$ & Stay-at-home \\
New Hampshire & $3 / 27 / 2020$ & Stay-at-home \\
New Jersey & $3 / 21 / 2020$ & Stay-at-home \\
New Mexico & $3 / 24 / 2020$ & Stay-at-home \\
New York & $3 / 22 / 2020$ & Stay-at-home \\
North Carolina & $3 / 30 / 2020$ & Stay-at-home \\
Ohio & $3 / 23 / 2020$ & Stay-at-home \\
Oklahoma & $3 / 25 / 2020$ & Safer-at-home \\
Oregon & $3 / 23 / 2020$ & Stay-at-home \\
Pennsylvania & $4 / 1 / 2020$ & Stay-at-home \\
Puerto Rico & $3 / 15 / 2020$ & Curfew \\
Rhode Island & $3 / 28 / 2020$ & Stay-at-home \\
South Carolina & $3 / 26 / 2020$ & Stay-at-home \\
Tennessee & $3 / 31 / 2020$ & Stay-at-home \\
Texas & $4 / 2 / 2020$ & Stay-at-home \\
Utah & $3 / 27 / 2020$ & Home \\
& &
\end{tabular}




$\begin{array}{lll}\text { Vermont } & 3 / 25 / 2020 & \text { Stay-at-home } \\ \text { Virginia } & 3 / 30 / 2020 & \text { Stay-at-home } \\ \text { Washington } & 3 / 23 / 2020 & \text { Stay-at-home } \\ \text { West Virginia } & 3 / 24 / 2020 & \text { Stay-at-home } \\ \text { Wisconsin } & 3 / 25 / 2020 & \text { Stay-at-home } \\ \text { Wyoming } & 3 / 28 / 2020 & \text { Safer-at-home }\end{array}$

The following states did not have state-wide stay-at-home orders.

Arkansas, Iowa, North Dakota, Nebraska, Oklahoma, South Dakota, Utah, Wyoming.

\section{COUNTY LEVEL CHANGES:}

\section{ALABAMA}

http://www.alabamapublichealth.gov/news/2020/03/19.html

Orders limiting public gatherings from 18 March.

3/19/20 State Health Officer Dr. Scott Harris has issued orders suspending certain public gatherings due to the risk of infection by the novel coronavirus COVID-19 effective from now until April 6. These orders are applicable for all Alabama counties.

On March 13, Gov. Kay Ivey declared a state public health emergency exists in Alabama.

\section{Jefferson County}

On March 16, in response to a rapidly growing number of cases of COVID-19 being detected in Jefferson County, Dr. Mark Wilson, Jefferson County health officer, issued health orders with similar restrictions. Dr. Harris added the counties surrounding Jefferson on March 17. Mobile County Health Officer Dr. Bernard Eichold ordered closures on March 18.

State Health Officer Dr. Scott Harris has issued orders suspending certain public gathering due to the risk of infection by the novel coronavirus COVID-19. These orders are applicable for the counties of Blount, St. Clair, Shelby, Tuscaloosa and Walker. The order is summarized as follows:

- Effective March 17, all gatherings of 25 people or more or gatherings of any size that cannot maintain a consistent six-foot distance between persons are 
prohibited in these counties. This order applies to all events or activities that bring 25 or more persons in a single room or single space at the same time.

- Effective March 18, all senior citizen centers are to be closed. Senior centers and their partners are urged to assure that their clients continue to receive needed meals via curbside pickup or delivery.

- Effective March 18 through April 6, all private schools (grades through 12) and preschools and childcare centers with 12 or more children, except for those operated within hospitals, shall be closed. Prior to April 6, a determination will be made about whether to extend these closures.

- All nursing homes and long-term care facilities will prohibit visitors, except for compassionate care situations such as end-of-life care.

- Effective at 5 p.m. March 17, any restaurant, brewery or bar shall not permit onsite food or drink to be served for at least one week, with certain provisions. Establishments may continue to offer food for take-out or delivery provided the social distancing protocols including maintaining a consistent six-foot distance between persons are followed. Establishments are strongly encouraged to offer online ordering and curbside pickup of food. Hospital food service areas are excluded provided they have their own social distancing plan.

More restrictions progressively, nail salons etc.

\begin{abstract}
ARIZONA
Governor Ducey ordered restaurants closed for dining-in and restrictions on public gatherings on 19 March

Schools close on 16 March
\end{abstract}

Mohave:

3/25/20 NPI restrictions put in place but not stay-at-home https://covid-19-mohave.hub.arcgis.com/

https://www.mohavecounty.us/ContentPage.aspx?id=441\&cid=1028\&page=1\&rid $=1601$

Until further notice, all bars, movie and stage theaters, indoor gyms and fitness clubs in Mohave County, including all those in the incorporated cities of Lake Havasu City, Bullhead City and Kingman, must closed to the public immediately. All restaurants must prohibit on-site dining but may continue to provide pick-up, delivery and drive-thru service. All restaurants should also be aware of the temporary modifications in the Executive Order related to the carry out of alcoholic beverages. 
(Guidance on this matter is provided on the State's Department of Liquor Licensing and Control website. )

Yuma County

Same as the state - direct call to Yuma county Public Health department.

\section{Apache County - Navajo Nation}

23 march 2020

https://www.lakepowelllife.com/navajo-nation-stay-at-home-order/

\section{ARKANSAS \\ Schools close 16 March \\ Miller County}

Some recommendations

No closures.

https://www.texarkanagazette.com/news/texarkana/story/2020/apr/02/updatemiller-county-coronavirus-cases-rise-seven-courthouse-closed-public-afteremployee-tests-positive/822934/

While Arkansas had no state-wide stay-at-home, Miller county did implement stayat-home following its neighbor Bowie county in Texas.

25 March

https://www.arklatexhomepage.com/news/texarkana-news/texarkana-issuesmandatory-curfew-due-to-covid-19/

"Both Texarkanas remain under a mandatory curfew from 10 p.m. to 6 a.m. The city of Texarkana, Arkansas, is asking residents to stay home if possible and to limit gatherings to 10 or fewer people." 


\section{CALIFORNIA}

\section{Imperial county}

http://www.icphd.org/health-information-and-resources/healthy-facts/covid19/media-resources/

Stay-at-home - same as state 19 March

Schools close 17 March

\section{Siskiyou}

Schools close 16 March

Nevada

Schools close March 16

\section{San Bernardino}

Schools close March 16 - decision taken on 13 March

\section{Colorado}

\section{Dine in restaurants closed 17 March}

https://www.coloradoan.com/story/news/2020/03/30/coronavirus-colorado-timelinedevelopments-during-covid-19-pandemic/2936681001/

\section{Weld}

County follows state. Re-opening planned 27 April

Schools close 16 March

\section{Larimer}

Stay-at-home effective 26 March

Schools close 16 March (Poudre school district)

https://www.coloradoan.com/story/news/2020/03/13/coronavirus-coloradopoudre-school-district-extends-spring-break/5042179002/ 
Re-opening -safer at home due on 27 april 2020

\section{La Plata (Durango)}

Schools closed form 16 March

https://the-journal.com/articles/171064

\section{Connecticut}

Counties followed state orders for stay-at-home.

School closures

https://www.fox61.com/article/news/health/coronavirus/connecticut-coronavirusupdates-march-12/520-ddfcc84c-1521-4354-907b-d53e2642bee9

\section{Tolland}

Schools 16 March

https://patch.com/connecticut/tolland/coronavirus-tolland-schools-closing-recschedules-altered

\section{Fairfield}

13 March

https://www.fox61.com/article/news/health/coronavirus/connecticutcoronavirus-updates-march-12/520-ddfcc84c-1521-4354-907b-d53e2642bee9

\section{New London}

16 March

https://patch.com/connecticut/newlondon/new-london-schools-close-duecoronavirus-concerns

\section{Delaware}


Counties followed state stay-at-home order.

School closures 16 March

\section{$\underline{\text { Florida }}$}

\section{Escambia county}

http://escambia.floridahealth.gov/newsroom/index.html

Did not close early https://www.pnj.com/story/news/2020/04/02/florida-stayhome-order-escambia-county-officials-urge-compliance/5115429002/

The Escambia County Commission will be debating Thursday if any further actions are needed to comply with the governor's order, such as ordering bingo parlors to close or to extend the closing of public beaches.

Morgan said he is depending on the County Commission and the city government to pass ordinances as needed for specific enforcement actions such as the emergency order to close the beaches.

"We've got all these different moving parts, and we're trying to find the appropriate path to victory over this virus," Morgan said.

\section{Nassau County}

https://fernandinaobserver.com/general/nassau-county-alerts-public-to-floridasrecently-in-acted-stay-at-home-order/

no early order

https://www.news4jax.com/news/local/2020/04/01/nassau-county-monitoringwhether-theres-some-type-of-spread-within-community/ 


\title{
Georgia
}

\author{
Richmond County
}

https://www.augustaga.gov/2785/COVID-19-Updates

$3 / 21 / 2020$ - 4:15pm

\section{AUGUSTA TO INITIATE BUSINESS AND GATHERING RESTRICTIONS DUE TO COVID-19}

Due to the necessity to preserve and protect the public, the city of Augusta, Georgia has decided to impose restrictions on certain businesses and social gatherings. This executive order will go into effect on March 22nd at midnight and will remain in place through April 4, 2020. The city reserves the right extend and/or expand imposed guidelines for the health and well-being of the public.

This order will restrict entertainment venues, gyms and fitness studios, body care, convention centers, and dine-in activity at bars and restaurants, and public events and private gatherings that would violate the Centers for Disease Control and Prevention (CDC) recommendation.

Per the order, the City of Augusta is mandating all the listed businesses to cease operations by the effective date and time.

Operations of these businesses, and both private and public gatherings, could violate the recommendation from the White House and CDC stating people should not gather in groups of 10 or more.

This order will not affect essential services. Those include, gas stations, pharmacies, grocery stores, food banks, convenience stores, banks, hospitals, medical centers, and laundromats. Restaurants providing take-out, drive thru, and delivery services can continue to do business.

Critical government functions such as water and sewer, garbage, transportation, jails, courts, law enforcement, fire protection, and emergency services will also continue operations.

"The time is now, for us as a city to act and protect the citizens of Augusta, Georgia," said Mayor Hardie Davis, Jr. "This is a virus that has no treatment plan, no vaccine, and continues to spread at a rapid rate. As a community, we must work together to protect each other." 
As of the March 21, 2020 noon update, the Georgia Department of Public Health has reported 507 confirmed positives cases of COVID-19 with 14 deaths. In Richmond County, there are nine confirmed cases. This number expected to rise in the coming days and possibly weeks.

\section{$3 / 16 / 2020-6: 05 p m$}

Like so many of you, I'm concerned about novel coronavirus, also known as COVID19. The City of Augusta, along with our community partners that includes the Department of Public Health, is working to ensure your health and safety as this virus continues to spread across Georgia and around the nation. Today, I along with the leaders who stand with me, took several specific steps to protect the health of everyone in our city:

- Effective today we are suspending public access and activities at all recreation facilities, government buildings and community centers until April1st;

- We are changing the event permitting policy to indefinitely suspend the approval of permits for public gatherings.

- City of Augusta permitted, sponsored and produced public events through the Recreation and Parks Department are suspended until April 1st;

- All Augusta public library branches will close to until April 1st;

- City of Augusta Senior Centers will be closed to the public until April 1st;

- All travel is being restricted for employees;

Nothing slows the spread of COVID-19 as effectively as social isolation, as frustrating as it may be. While these decisions are not made easily, and we know how frustrating they will be for many citizens, we have a responsibility to act in the best interests of everyone's health and safety.

That goes for our employees too. Today the City of Augusta began implementing Continuity of Operations Plans (COOPs) that have been prepared by our department heads under the direction of the Interim Administrator and EMA Director.

The COOPs allow for some telecommuting in order to reduce the number of employees in city offices and facilities at any given time. Please know that core services such as trash and brush pickup, police and fire services will not be reduced.

Please continue to refrain from large public gatherings. The White House has issued new guidance this afternoon recommending that people not gather in groups larger than 10 people. I want to urge our local businesses to act in accordance with those recommendations as we will for City of Augusta operations. 
Stay home if you feel sick and call your primary care provider before coming to a walk-in clinic or emergency room. Wash your hands, disinfect hard surfaces, and avoid physical contact. The safety and health of our community and employees are the top priority and we appreciate everyone's patience during this time.

Our government will continue to serve the people of Augusta. We are taking every precaution to limit the spread of the virus in our community.

Mayor Hardie Davis, Jr.

\section{Catoosa County}

Closed schools on 12 March

https://www.timesfreepress.com/news/local/story/2020/apr/05/weektennessee-and-georgigot-board-stay-home/519950/

Nothing evident for early stay-at-home although some restrictions earlier, schools and large gatherings etc.. Maybe in the 10 days before 3 April

https://www.catoosa.com/corona-covid-19

https://georgiarecorder.com/2020/04/03/georgia-coastal-officials-discouragetourists-ahead-of-state-shutdown/

\section{Camden County}

March 25 curfews/restaurants closed

https://www.firstcoastnews.com/article/news/health/coronavirus/voluntarycurfew-issued-for-camden-county-residents-amid-covid-19-outbreak/77cc407393-5bef-496c-898f-73151d638d6c

\section{$\underline{\text { IDAHO }}$}

\section{Kootenai County}


16 March early restrictions

Closing schools 16 March in Coeur d'Alene

"Early this week, government officials in Coeur d'Alene, Post Falls, Hayden, Rathdrum, Spirit Lake, Hayden Lake, Hauser, Huetter and Athol began ordering all bars and dine-in restaurants to close to stop the spread of the novel coronavirus. The state board of education ordered all public schools that hadn't done so already to close until at least April 20 on Monday. Written 25 March")

https://www.spokesman.com/stories/2020/mar/25/kootenai-county-confirms9th-covid-19-case-8-appea/

http://panhandlehealthdistrict.org/news/

\section{ILLINOIS}

\section{St. Clair}

Nothing found for early closures

\section{McHenry}

Officials want to re-open earlier - nothing found for early restrictions- some recommendations from public health department to limit non-essential gatherings on or around 11 march

\section{Madison}

Schools closed from 13 March

http://ecusd7.org/category/alerts-notifications/page/2/

Early re-open as of 13 May 2020

https://www.nbcchicago.com/news/local/madison-county-begins-reopening-indefiance-of-stay-at-home-order/2271380/

\section{Cook County}


No deviation from state

\section{Winnebago}

https://rockfordil.gov/preparing-for-covid-19/

On March 12, Winnebago County joined with Boone, DeKalb and Ogle Counties to recommend businesses, institutions, and organizations suspend all public gatherings and events of 25 people or more until further notice as a proactive method to limit the spread of the disease. On March 16, President Trump recommended that gatherings be limited to under 10 people.

\section{RESTAURANTS/BARS}

On March 15, Gov. J.B. Pritzker ordered all restaurants and bars to close to dine-in customers from March 16 through March 30. He's encouraging commercial kitchens to remain open for curbside pickup and drive thru services for customers where possible.

In an effort to alleviate the impact the Stay-at-home order has had on restaurants, bars and the hotel and tourism industry, the City is deferring collection of our Food and Beverage Tax and our Hotel-Motel Tax.

For more information on recent liquor sale changes, click here.

For a list of local restaurants offering take-out and delivery, see the lists from Explore 815 and the Rockford Area Convention and Visitor's Bureau.

\section{PUBLIC GATHERINGS}

On March 12, Winnebago County joined with Boone, DeKalb and Ogle Counties to recommend businesses, institutions, and organizations suspend all public gatherings and events of 25 people or more until further notice as a proactive method to limit the spread of the disease. On March 16, President Trump recommended that gatherings be limited to under 10 people.

\section{SCHOOLS}

On March 13, Governor J.B. Pritzker directed all public and private schools be closed from Tuesday, March 17, through Monday, March 30. Please consult your child's school district for specific plans during the school closure.

On March 20, Governor Pritzker announced the closure would be extended until at least April 8. On March 31, the Governor extended the closure through April. On April 17, the Governor announced that schools would be closed for the remainder of the academic year. 


\section{Lake}

Found nothing on early restrictions

\section{Rock Island}

Nothing early

http://richd.org/wordpress/wp-content/uploads/2020/03/COVID-19-mediaBriefing-3-17-20.pdf

\section{INDIANA}

Schools closed on 19 March

https://www.indystar.com/story/news/local/hamiltoncounty/education/2020/03/22/north-elementary-teachers-have-car-parade-seestudents/2895527001/

Some counties had "Travel restrictions"

\section{La Porte}

Nothing early.

\section{St Joseph}

The St. Joseph County Commission President Andy Kostielney said the county has been following the governor's lead since the beginning of the pandemic, and they will continue to do so. But like everyone else in the state, they're anxiously waiting to see what the governor will say during his briefing tomorrow. 
IOWA

Schools closed state-wide on 2 April (same for Nebraska)

https://qctimes.com/news/local/education/iowa-schools-ordered-to-close-through-april30/article 07616413-3f6e-5472-9ff4-9e8aa669279e.html

\section{Scott County}

Recommended smaller gatherings and closure of some city facilities 16 March

\section{Pottawattamie}

Lots of closures including schools in council Bluffs as of 16 March

https://www.nonpareilonline.com/news/special coverage/updated-list-of-councilbluffs-southwest-iowa-and-metro-area-cancellations-postponements-andclosures/article f75b9df1-fe92-51ae-9ea0-e347d29095e3.html

\section{$\underline{\text { KANSAS }}$}

\section{Wyandotte county}

21 March Stay-at-home in conjunction with Kansas City metro area.

https://www.wycokck.org/WycoKCK/media/Health-Department/Documents/UGSAH-FAQ-WY-Stay-At-Home-Order-03222020.pdf

Schools closures in Kansas and Kansas City, Missouri as of 17 March

https://fox4kc.com/tracking-coronavirus/metro-school-districts-canceling-forweeks-due-to-coronavirus-check-school-closings-here/

\section{KENTUCKY}

State stay-at-home on 23 March 


\section{Jefferson}

Schools closed 16 March

https://www.wdrb.com/in-depth/strong-possibility-that-school-closures-could-beprolonged-jcps-superintendent/article 6da094da-67b1-11ea-a237-

43e6a9b7954a.html

\section{Boone County}

Schools closed on 16 March

https://www.kentucky.com/news/local/education/article241115226.html

\section{LOUISIANA}

Statewide stay-at-home on 23 March

Earlier closures of schools and non-essential businesses on 13 march

https://gov.louisiana.gov/index.cfm/newsroom/detail/2403

Gov. John Bel Edwards today signed a proclamation that among other actions immediately halts any gathering of more than 250 people until Monday, April 13, closes all K-12 public schools statewide effective Monday, March 16 resuming Monday, April 13, as Louisiana seeks to slow the spread of COVID-19 in the state. As of mid-day Friday, Louisiana has 33 presumptive positive cases of COVID-19.

\section{Caddo Parish}

https://www.shreveporttimes.com/story/news/local/2020/04/02/howcaddo-bossier-doing-stay-home-order-not-so-good/5110663002/ 


\section{MAINE}

March 31 early action in Maine not stay-at-home.

https://www.seacoastonline.com/news/20200331/york-considers-rsquostay-athomersquo-order-after-townrsquos-first-coronavirus-death

However, Gov. Janet Mills on Tuesday issued a "Stay Healthy at Home" directive that requires residents to stay-at-home at all times unless for an essential job or an essential personal reason, such as obtaining food, medicine, health care or other necessary purposes.

Schools closed on 16 March in nearly all of Maine

\section{York County}

Studies a stay-at-home on 31 March

\section{MARYLAND}

In a video message, Montgomery County Executive Marc Elrich said he supports the actions of Maryland Governor Larry Hogan who ordered all restaurants, bars, theaters and gyms in the state to close as of 5 p.m. Monday, March 16.

This included school closures on 16 march

https://www.wusa9.com/article/news/local/maryland/coronavirus-montgomery-schoolclosure/65-12ddb36b-a252-405d-82de-ae8c72b9e6aa

March 23

Governor of Maryland closed all non-essential businesses.

https://www.washco-md.net/news/covid-19-joint-information-center-update-march-23$\underline{2020 /}$ 
https://jewishtimes.com/105326/baltimore-community-experiences-historic-lockdownin-response-to-coronavirus/news/local-news/

In a historic move, the Maryland General Assembly cut session early for the first time since the Civil War, according to the Baltimore Sun. It ended three weeks early, March 15. As the political voice of Baltimore's Jewish community, the BJC had to recalibrate.

https://wtop.com/coronavirus/2020/05/coronavirus-timeline-key-dates-as-the-virusspread-in-dc-maryland-and-virginia/

\section{Montgomery county}

https://www2.montgomerycountymd.gov/mcgportalapps/Press Detail.aspx?Item I $\underline{\mathrm{D}=23985}$

In a video message, Montgomery County Executive Marc Elrich said he supports the actions of Maryland Governor Larry Hogan who ordered all restaurants, bars, theaters and gyms in the state to close as of 5 p.m. Monday, March 16.

\section{Frederick County}

Reopening https://www.localdvm.com/news/i-270/executive-jan-gardner-makesdecision-on-reopening-frederick-county-at-3pm/

\section{MASSACHUSETTS}

Nantucket tried to close on the 23 of March

https://www.boston25news.com/news/coronavirus-live-blog-msp-warning-aboutcovid-19-thefts/WUF4Z3XGGVDVBES6E3WMOCJYRQ/

School closures on March 16 


\section{MICHIGAN}

State level closing of schools etc. earlier than state order for stay-at-home.

March 16 order issued for school closures on Friday 13 March.

https://www.michigan.gov/coronavirus/0,9753,7-406-98163-521561--,00.html

Timeline: https://www.clickondetroit.com/news/michigan/2020/04/14/coronavirus-inmichigan-a-timeline-of-closures-event-bans-stay-at-home-orders/

Whitmer, who declared a state of emergency when Michigan had its first positive tests for coronavirus March 10, earlier closed the state's schools, bars, gyms, theaters and other major gathering places, and ordered restaurants closed except for carryout and delivery services. On the weekend, she ordered hair and nail salons, barbershops and other personal service shops, such as tattoo parlors, closed.

https://www.freep.com/story/news/local/michigan/2020/03/23/michigan-shelter-inplace-order-coronavirus/2887578001/

\section{Monroe County}

No deviation from state policy.

\section{$\underline{\text { Minnesota }}$}

MN closed schools from 18 March

https://www.rivertowns.net/news/education/5000086-Minnesota-to-close-K-12-schoolsfor-8-days-starting-Wednesday-Heres-what-local-districts-are-doing

\section{Washington County}

South Washington county started earlier to close schools on 16 March

\section{MISSISSIPPI}

State governor recommends restaurant closures already as of 20 March 
https://www.localmemphis.com/article/entertainment/businesses-remain-open-indesoto-county-despite-the-outbreak-of-covid-19/522-b8324b24-71b2-42c9-b396$\underline{190781 d 122 \mathrm{c} 3}$

\section{De Soto}

Schools closed from 16 March

\section{Jackson}

Schools closed from 19 March

https://www.clarionledger.com/story/news/2020/03/13/ms-coronavirus-listschool-closures-state-metro-jackson-area/5038070002/

\section{MISSOURI}

\section{Orders by county}

https://themissouritimes.com/coronavirus-in-missouri-which-counties-haveimplemented-stay-at-home-rules/

\section{St Louis}

Stay-at-home order issued on 23 March.

Schools close by latest 18 March

https://www.stlmag.com/news/st-louis-school-closings-during-coronavirus/

\section{St Charles}

Closes schools on 18 March along with St Louis.

https://www.stlmag.com/news/st-louis-school-closings-during-coronavirus/

Beginning at 12:01 a.m. on March 24, those in the city of St. Joseph "are strongly encouraged to shelter in place by remaining in their respective residences, avoiding contact with people with whom they do not reside, and avoiding public places 
except when necessary to obtain food, supplies, and medical treatment," according to the order.

\section{Kansas City}

21 March

https://themissouritimes.com/coronavirus-in-missouri-which-counties-haveimplemented-stay-at-home-rules/

\section{NEBRASKA}

\section{Douglas County}

Schools closed from 19 March.

Nebraska Governor Pete Ricketts released the state's first Directed Health Measure (DHM) in response to the spread of the coronavirus. It will apply to all communities in Educational Service Units (ESU) \#3 and \#19 which include Cass, Douglas, Sarpy, and Washington counties.

https://www.3newsnow.com/news/coronavirus/directed-health-measuresreleased-by-governor-ricketts-office

Last week, the confirmation of a second case of community spread of the coronavirus in Douglas County - a 46-year-old man whose illness had no known source - resulted in Ricketts closing schools in Cass, Douglas, Sarpy and Washington Counties for six to eight weeks. He also ordered restaurants and bars in those counties to close their dining areas immediately and move to takeout, delivery or curbside-only service until further notice.

Douglas County health officials already had issued a public health order prohibiting all public gatherings with more than 10 people through April 30. 


\section{NEVADA}

Early action on 16 March http://gov.nv.gov/News/Emergency Orders/2020/2020-03-17 Governor Sisolak Announces COVID-19 Risk Mitigation Initiatives/

Non-essential businesses closed, gaming machines closed etc.

Schools closed all of Nevada form 16 March

\section{NEW JERSEY}

Moved early from 16 March closing cinemas, gyms and casinos (coordinated with NY and CONN)

See executive order.

Also the article says

With many school districts already closed and some local towns having issued quarantine and curfew orders, Murphy's near-lockdown of the entire state started here.

https://www.nj.com/coronavirus/2020/04/murphy-has-issued-24-executive-orders-tohelp-slow-coronavirus-outbreak-in-nj-heres-the-timeline.html

https://www.nj.com/coronavirus/2020/03/coronavirus-closures-updated-list-of-njschool-districts-that-are-closing-or-changing-schedules-wednesday-march-11.html

\section{Passaic County}

\section{Camden County}

Shutdown since March 21

https://patch.com/new-jersey/gloucestertownship/heres-how-well-camdencounty-complies-stay-home-order

\section{NEW YORK}

Schools close on 16 March (Ulster, Orange, and Dutchess) 
https://www.dailyfreeman.com/news/local-news/all-schools-in-ulster-dutchess-orangecounties-to-close-for/article eecac70e-6551-11ea-a90e-a39dde3ca2dchtml

\section{Westchester county}

"Containment area" and college closures in NY area start 10 March.

\section{Dutchess County}

Same as New York state

\section{NORTH CAROLINA}

State shutdown on 27 March but

Stay-at-home orders by the city of Durham, Wake County and Mecklenburg County already restrict movement by the public except for essential jobs and tasks such as those related to health and food.

https://www.newsobserver.com/news/coronavirus/article241469211.html

Schools closed in North Carolina on 16 March.

\section{Mecklenburg County}

But according to here Mecklenburg County shut down on 24 March. https://www.mecknc.gov/news/Pages/Stay-at-Home-Order-March-24.aspx Limited mass gatherings on 17 March https://www.mecknc.gov/news/Pages/Stay-at-Home-Orders-Clarification-andGuidance-Update.aspx

\section{Henderson County}

Schools close with state on 16 March https://www.blueridgenow.com/news/20200314/nc-governor-closes-schoolshenderson-county-working-on-rsquolearn-from-homersquo-model

Stay-at-home 28 March 
"We anticipate that within the next week 15-20 in Henderson County will have Covid-19," said President/CEO of Pardee Hospital, Jan Kirby. "We anticipate 500 patients and of that, 250 on ventilators and you can do the math from there. Pardee Hospital has 18 ventilators. That is woefully under what we need."

https://wlos.com/news/local/henderson-county-officials-approve-stay-at-homeorder-goes-into-effect-saturday

\section{Brunswick County}

No stay-at-home earlier than state.

Schools close on 16 March

https://portcitydaily.com/local-news/2020/03/14/gov-cooper-orders-all-northcarolina-public-k-12-school-classes-canceled-for-at-least-two-weeks-free-read/

\section{Haywood County}

Schools close 16 March

https://www.themountaineer.com/news/haywood-schools-announces-plan-amidclosure-news/article 108226a8-663d-11ea-8b6f-6317908603cc.html

Stay-at-home 26 March

https://www.themountaineer.com/news/local/county government/haywoodresidents-urged-to-stay-at-home/article 1f0007f4-6f84-11ea-ab919be729c2b68c.html

\section{Gaston County}

School Closures 16 March

Stay-at-home 27 March

The stay-at-home order comes after a resident of Gaston County tested positive for the coronavirus through community spread. As of Thursday at 3 p.m. there were 11 positive cases of COVID-19 in Gaston County.

https://www.wcnc.com/article/news/local/gastonia/gaston-county-residentsunder-stay-at-home-starting-friday/275-31ad3ca5-4af1-4725-8948-abb294e43aa0 


\section{$\underline{\text { OHIO }}$}

\section{Hamilton County}

Schools close 16 March

Stay-at-home 23 March

\section{Lucas County}

Schools close 16 March

https://www.toledoblade.com/news/medical/2020/03/12/ohio-orders-ban-onmass-gatherings/stories/20200312137

\section{OREGON}

\section{Multnomah County}

Stay-at-home with Oregon 23 March.

https://www.opb.org/news/article/oregon-coronavirus-stay-at-home-stayhealthy/

School Closures March 16 all of Oregon. Some districts had closed 1 or 2 days earlier https://www.opb.org/news/article/oregon-coronavirus-statewide-schoolclosures-live-updates/

Additional bans of gatherings of more than 250 people on 12 March

\section{Umatilla County}

Shut down from 15 March and phasing out from 12 March

https://pendleton.k12.or.us/announcements-news/page/4/

\section{Josephine}

School Closures and stay-at-home with state 16 and 23 March

\section{Jackson}

School Closures and stay-at-home with state 16 and 23 March 


\section{PENNSYLVANIA}

Phased in stay-at-home. Pittsburgh and Philadelphia earlier and then other counties.

23 March

Noting that Philadelphia has already ordered residents to remain home, Wolf issued his own stay-at-home order for the counties around the city; for Allegheny County, which includes Pittsburgh; and for Monroe County in the Pocono Mountains.

This happened on 27 March. Wolf, in a statement, added York and eight other counties to 10 already covered by the order, for a total of 19 counties and threefourths of the state's 12.8 million residents.

The stay-at-home order started at 8 p.m. Friday for Berks, Butler, Lackawanna, Lancaster, Luzerne, Pike, Wayne, Westmoreland and York counties, and will last until at least April 6.

https://www.yorkdispatch.com/story/news/local/2020/03/27/york-countyresidents-under-stay-home-order/2927436001/

https://www.yorkdispatch.com/story/news/local/pennsylvania/2020/03/26/govwolf-extends-stay-home-order-two-counties/111464776/

https://www.yorkdispatch.com/story/news/coronavirus/2020/03/23/wolf-issuestay-home-order-hardest-hit-counties/2900117001/

\section{York}

27 March Stay-at-home

\section{Philadelphia}

$22 \mathrm{March}$

https://www.phila.gov/2020-03-22-city-issues-stay-at-home-order-clarifyingrestrictions-on-business-activity-in-philadelphia/

\section{Monroe}

Stay-at-home 23 March

\section{Washington}

Stay-at-home 28 March 
https://observer-reporter.com/series/coronavirus/governor-expands-stay-athome-order-to-include-washington-county/article b5185904-7113-11ea-aa50e7ae6ffbf72a.html

\section{Delaware}

Stay-at-home 23 March

Order Effective at 8:00 PM in Allegheny, Bucks, Chester, Delaware, Monroe, Montgomery, and Philadelphia counties

https://www.governor.pa.gov/newsroom/governor-wolf-and-health-secretaryissue-stay-at-home-orders-to-7-counties-to-mitigate-spread-of-covid-19/

\section{Chester}

Stay-at-home 23 March

\section{Adams}

Stay-at-home 1 April

https://gettysburgconnection.org/adams-county-residents-ordered-to-stay-athome-as-county-covid-19-cases-jump-33-percent/

\section{Erie County}

Stay-at-home 24 March

\section{Franklin}

Stay-at-home 31 March

https://www.publicopiniononline.com/story/news/local/2020/03/31/coronaviru s-pa-franklin-county-added-stay-home-order/5095993002/

\section{RHODE ISLAND}

Stay-at-home 28 March

Some business closures for restaurants etc. two weeks before 2 April on 17 March https://en.wikipedia.org/wiki/COVID-19 pandemic in Rhode Island\#cite note-11 https://ri-department-of-health-covid-19-data-rihealth.hub.arcgis.com/ https://www.bostonglobe.com/2020/03/28/metro/rhode-island-records-it-first-twodeaths-coronavirus/ 
For the other counties in the sample we mark 16 March as the start of NPIs- this is when schools were closed throughout the state. Some other schools had closed earlier though.

\section{Providence}

March 12 restrictions on entertainment licenses

List, Madeleine. "Providence mayor issues state of emergency, revokes entertainment licenses". providencejournal.com. Retrieved March 28, 2020.

https://en.wikipedia.org/wiki/COVID-19 pandemic in Rhode Island\#cite note-11

\section{SOUTH CAROLINA}

Schools closed on 16 March.

Dine in restaurants closed on 17 March

\section{Aiken}

Council wants more social distancing on 3 April

https://www.aikenstandard.com/news/better-safe-than-sorry-aiken-city-councilrequests-stay-at-home-order-from-s-c/article c5d67b90-751e-11ea-8b20$\underline{\text { 036f139acbb5.html }}$

Aiken County is in a unique position compared to other counties in South Carolina in that Aiken County abuts the Georgia border. Georgia Gov. Brian Kemp issued an Executive Order earlier this week instructing residents to "shelter in place" in their residences except to conduct essential business. The order went into effect at 6 p.m. Friday and is currently set to expire at 11:59 p.m. on April 13.

"We're the one state in the country that hasn't called for a shelter in place," Council member Ed Woltz said. "The fact that we haven't done it yet as a state is disappointing to me. I think it sends a message of what we think about ourselves, and what we think about other people in the country."

\section{Horry}


No advance stay-at-home. Conway City council had considered on 6 April but the governor passed statewide stay-at-home on 7 April

https://www.myhorrynews.com/news/local/conway/update-conway-considersstay-at-home-ordinance/article 03a6ebc0-7818-11ea-b3c5-ff3d8f91d760.html

\section{Greenville}

City council of Greenville passed more social distancing measures on 3 April. These are not very strong and did not include bans on public gatherings. Schools already closed.

https://www.foxcarolina.com/news/greenville-city-council-passes-ordinance-toenact-stricter-social-distancing-measures-asks-mcmaster-toissue/article 9b5a6cca-750d-11ea-8925-bbd4e8085d26.html

\section{TENNESSEE}

Restaurants and public gatherings of larger than 10 people banned from 22 March https://www.tennessean.com/story/news/health/2020/03/22/tennesseegovernor-restaurants-bars-closed-takeout-and-delivery/2892481001/

Safer at home 30 March

Stay-at-home 2 April

Closed schools on 16 March

https://www.timesfreepress.com/news/local/story/2020/apr/05/week-tennessee-andgeorgigot-board-stay-home/519950/

\section{Shelby}

Memphis and Shelby county order stay-at-home on 24 March https://en.wikipedia.org/wiki/COVID-19 pandemic in Tennessee

Schools closed on 13 March https://www.scsk12.org/coronavirusfacts/ 


\section{Cocke}

Schools close 16 March

City Council of Newport closes on 20 March

https://www.cityofnewport-tn.com/

\section{Hamilton County}

The county ordered a more restrictive stay-at-home order than the state on 4 April but the state had already imposed safer at home and shelter in place (2April)

https://wdef.com/2020/04/02/stay-place-order-issued-chattanooga/

\section{Orange County}

More strict stay-at-home announced 27 March

It was announced today that as of 11:59 pm today, March 27, 2020, Orange County along with Jefferson, Jasper, Newton, Hardin, and Tyler Counties will begin a more stringent Stay-at-home, Work Safe Order for all six counties.

Restaurants closed 17 March

https://www.ocregister.com/2020/03/17/orange-county-expected-to-ban-allgatherings-close-bars-and-limit-restaurants-to-take-out/

School closure 17 March

https://www.beaumontenterprise.com/news/article/Vidor-West-Orange-CoveISD-s-close-due-to-15135814.php

\section{NEW HAMPSHIRE}

School closures on March 15

People asking for closures but not getting them on 24 March.

https://www.sentinelsource.com/news/health/state-local-residents-push-governor-forshelter-in-place-order/article 8104a41a-0e92-5c30-ae0b-2d0da06014ac.html 
TEXAS

Bowie County (Texarkana)

Business closures on 19 March 2020

https://www.ci.texarkana.tx.us/CivicAlerts.aspx?AID=234

Stay-at-home March 27-2020

https://www.bowiecountynow.com/news/corona-virus-update-march-27-2020

https://txktoday.com/news/bowie-county-issues-shelter-in-place-order/

Schools closures 16 March

https://txktoday.com/featured-2/texarkana-covid-19-closures/

\section{$\underline{\text { UTAH }}$}

Schools closed 13 March

18 March State limits on public gatherings to less than 10, no dining in, no visits to nursing homes

\section{Washington}

Utah state issues "stay safe, stay home", county follows the state directive.

Governor Gary R. Herbert has issued a "Stay Safe, Stay Home" directive to all Utahns. This is not a shelter in place order, but rather the next step in the Urgent Phase laid out in the Utah Leads Together plan. This directive seeks to make clear what individuals and businesses should do to slow the spread of COVID-19 in our state and communities.

Goals of the directive are to flatten the curve, reduce the strain on hospitals and the healthcare system, and minimize the impact on medical resources for those with highest need.

https://kutv.com/news/local/coronavirus-heres-which-utah-counties-areordering-residents-to-stay-at-home https://swuhealth.org/covid-archives/ 


\section{VIRGINIA}

Schools closed for 2 weeks on 13 March

18 March limited public gatherings of more than 10 people including dine-in restaurants

https://www.loudountimes.com/news/gov-northam-issues-order-limiting-publicgatherings-to-people/article 56b3ea1a-68f6-11ea-bea9-cbe3ecfbd2c6.html

State wide stay-at-home 30 March (or possibly 24 March) There was an executive order on 24 March that looked like stay-at-home. It had to be strengthened on 30 March to something like shelter in place

On March 23, Northam issued an order that banned within Virginia all gatherings of more than 10 people. The order required all public schools to be closed for the remainder of the current school year. The order also closed all public access to recreational and entertainment businesses, such as bowling alleys, gyms, and theaters. [77]

The March 23 order closed "dining and congregation areas" in restaurants, dining establishments, food courts, farmers markets, breweries, microbreweries, distilleries, wineries and tasting rooms, but left open all other areas in those types of businesses. The order also left open certain specified "essential retail businesses" including pharmacies, grocery stores, and banks (among others

\section{Loudon}

Schools close 12 March Loudon county

https://en.wikipedia.org/wiki/COVID-19 pandemic in Virginia

\section{Fairfax}

Schools close 13 March

23 March executive order

\section{WASHINGTON}


Schools close statewide on 13 March

15 March public gatherings and dine-in restaurants order

On March 15, Governor Inslee announced the closing of all sit-down restaurants statewide, noting that "very strong measures are necessary to slow the spread of the disease". Restaurants are still allowed to offer takeout and drive through options.[165][166] The governor also announced that he would issue an emergency proclamation ordering all entertainment and recreation facilities to temporarily close.167] The same order banned gatherings of groups of 50 or more statewide.[168]

Statewide stay-at-home 23 March

\section{Benton County}

Tri-cities schools announced closed from 17 march. Announcement was made on 13 March

\section{Clark County}

Schools close from 16 March announced on 13 March

https://www.columbian.com/news/2020/mar/13/clark-county-schools-to-close-for-sixweeks-over-covid-19-concerns/

\section{Spokane}

No evidence of deviation from state dates.

\section{WEST VIRGINIA}

Schools close statewide from 16 March announced on 13 March

https://en.wikipedia.org/wiki/COVID-19 pandemic in West Virginia

Restaurants and casinos closed on 17 March

On March 17, Justice ordered restaurant dining rooms, bars, and casinos to close until March 31

Statewide stay-at-home 24 March 


\section{Ohio}

Appears that closures coincide with state orders

https://wtov9.com/news/local/west-virginia-stay-at-home-order-takes-effect

\section{WISCONSIN}

Gatherings of more than 50 people limited statewide 16 March

Restaurants and bars closed and gatherings limited to less than 10 in Wisconsin from 17 March 5PM.

https://patch.com/wisconsin/mountpleasant/all-wisconsin-bars-restaurants-orderedclosed-72-covid-19-cases

https://en.wikipedia.org/wiki/COVID-19 pandemic in Wisconsin

Counties defying re-opening:

https://www.channel3000.com/list-of-counties-that-have-enacted-a-local-safer-at-homeorder-through-may-26/

\section{Kenosha}

Schools closed form 16 March

https://www.kusd.edu/news/covid-19-coronavirus

Kenosha city limited large official meetings on 12 March

https://www.kenoshanews.com/news/local/city-suspends-large-publicgatherings-expands-early-voting-amid-virus/article 61658645-a272-5e4e-ab65$\underline{55 \mathrm{a} 0 \mathrm{~b} 80 \mathrm{c} 3982 . \mathrm{html}}$

\section{Rock}


No evidence of an early order

https://www.co.rock.wi.us/publichealth-familycommunity/publichealthcommunicabledisease/coronavirus-disease-2019\#rock-county-public-healthdepartment-daily-updates

Issued stay-at-home on 13 May- after Wisconsin Supreme court overturns state order.

\section{St Croix}

No deviation from state

\section{WYOMING}

19 March State limits gatherings of more than 50 people, dine-in restaurants, bars, gyms etc.

Governor further urges people to stay-at-home and non-essential personal services to close effective 25 March

\section{Laramie}

No stay-at-home

https://patch.com/wyoming/cheyenne/no-stay-home-orders-place-laramie-county

Nearby Larimer County - located in northern Colorado - issued a stay-at-home order on Wednesday, March 25. Due to similar spelling and proximity of these two counties, we wanted to reiterate that message to our Laramie County residents.

Although there is no lock down or stay-at-home orders for Laramie County, all Wyoming residents are urged to stay home whenever possible as announced by Governor Mark Gordon on Wednesday afternoon. More information on Governor Gordon's announcement can be found here.

Schools close on 16 March 
https://oilcity.news/community/health/covid-19/2020/03/15/laramie-countyschool-district-closes-schools-at-least-through-april-7/ 